\title{
MATRIMONIAL PROPERTY - THE NEW REGIME
}

\author{
PETER J. M. LOWN* AND FRANCES L. BENDIAK* *
}

On January 1, 1979, the Alberta Legislature enacted the Matrimonial Property Act governing property rights between married persons upon marital breakdown. The authors examine the legislation and attempt to answer questions likely to be of interest to practising lawyers, such as: Under what cir. cumstances can an Alberta court take jurisdiction in a matrimonial property application? What property is governed by the Act? What factors will the court consider when exercising the discretion granted to it under the Act? What are the special rules relating to matrimonial home possession? In analysing these and other issues, the authors examine the wording of the legislation in light of its policy, and speculate upon ambiguities that must await judicial pronouncement for resolution. They point out that, depending upon the approach taken by the courts in construing the Act, the overall policy, to determine what is a fair and equitable distribution of the property between the parties, may or may not be accomplished.

The authors acknowledge the assistance of Professor L. J. Pollock, whose consultation, advice, and suggestions have been most helpful.

\section{INTRODUCTION}

On January 1, 1979, the Matrimonial Property Act * * was proclaimed in force in Alberta. Bearing in mind the decisions of the Supreme Court of Canada which gave impetus to the clamour for the amendment of the rules regulating property rights between married persons, and having regard to the lengthy if not tortuous process which the recommendations endured, one might legitimately expect the resulting act to have a significant impact on Alberta society. Whether the legislation is merely jumping on the bandwagon of changes in Matrimonial Property regimes, pandering to popular request, or whether it is a genuine and successful attempt to modernize and realign the rules, will not become clear for some time to come. Furthermore, the result will depend on a number of factors, not the least of which is the level of understanding of the purposes and policies of the new legislation.

It would be an understatement to say that the results of litigation in the matrimonial property area in the past could not be predicted with any certainty. Vital questions and principles might turn on a chance phrase such as "I thought we was to be a team",' or the willingness of one judge to use a legal concept thought by others to be daring and avant-garde in its application to matrimonial property. ${ }^{2}$

* LL.B. (Honours) Glasgow, LL.M. (Sask.). Associate Professor, Faculty of Law, University of Alberta. Member of the Law Society of Alberta.

-* B.A. (Alta.). Of the graduating class, Faculty of Law, University of Alberta, 1979.

*. It would be beneficial if the reader had available a copy of the full text of the Matrimonial Property Act, S.A. 1978, c. 22, while reading this article.

1. Murdoch v.Murdoch (1977) 26 R.F.L. 1; Fiedler v. Fiedler (1975) 20 R.F.L. 84; Rathwell v. Rathwell [1978] 2 W.W.R. 101

2. Rathwell v. Rathwell, supra $\mathrm{n} .1$ at 105 :

The venture was a "joint effort" in which Mr. Rathwell said he and his wife "worked as a team, to start with". Mr. Rathwell acknowledged that his wife contributed "to an extent". It was to a considerable extent. 
While it is not the purpose of this article to analyse and describe at length the formerly applicable rules of law in respect of matrimonial property, some summary must be attempted in order to provide at least a modicum of background information. ${ }^{3}$

At common law, upon marriage, the wife ceased to be capable, for all practical purposes, of owning or controlling property. The marriage ceremony vested the property of the woman in her husband, and from that point forward the woman had to trust to her husband's good management for her well-being. The quid pro quo, if that is appropriate, was the wife's ability to pledge her husband's credit for necessaries, her right to be maintained (of course, dependent on her good behavior) and her right to have property "settled to her separate use".

One might argue that such a system was advantageous if its use and application were limited to a harmonious marital relationship and if some other rules became applicable upon separation, divorce or death. ${ }^{5}$ Such was not the case; and "the beauty of the common law", ever adaptable and pliable, had to be called in aid to alleviate the effects of such an intransigent property system.

A number of exceptions arose therefore, which could be used to obviate the results of the common law rules. ${ }^{6}$ These exceptions may be divided into two categories:

(i) where the parties have agreed, or so acted as to imply that they own or share property equally or in a definable proportion; or

(ii) where, in the absence of any express or implied agreement between the parties, it would be unfair not to find the parties to be equal or proportionate owners.

Thus the arguments have raged around contributions by one spouse to the purchase of property by the other, ${ }^{7}$ gifts by one spouse to the other, ${ }^{8}$ the value of non-monetary as opposed to monetary contributions, ${ }^{\circ}$ and the ques-

3. Rathwell v. Rathwell, supra n. 1. Compare the approaches adopted by Dickson, J. and Martland, J.

4. The reader is directed to two articles previously appearing in the Review (vol. XVI) wherein this subject is treated at greater length:

a. Dr. O. M. Stone, "Matrimonial Property Law: The Movement Towards Equality Separation or Community?" (1978) 47 A.L.R. 375.

b. L. J. Pollock, "Matrimonial Property and Trusts: The Situation From Murdoch to Rathwell" (1978) 47 A.L.R. 357

5. The "freedom of testation" became such a sacrosanct part of the Common Law that any pretence that the husband merely managed his wife's property, as opposed to owning it, was patently transparent.

6. See for example, the Divorce Act, R.S.C. 1970,c. D-8, ss. 10-12; the Domestic Relations Act, R.S.A. 1970, c. 13, Part 3, ss. 16-26; the Family Relief Act, R.S.A. 1970, c. 134, 8s. 4-10.

7. Fiedler v. Fiedler, supra n. 1.

8. Presumption of advancement based on a gift, Kellas et al. v. Chapman (1972) 27 D.L.R.(3d) 121.

9. Murdoch v. Murdoch, supra n. 1; Rathwell v. Rathwell, supra n. 1. 
tion of what one spouse might do or not do as part of natural love and affection. ${ }^{10}$

All of these inroads amounted to something less than a full frontal evaluation of and attack on the propriety of the common law system. Not so the Alberta proposals, which were to stand the tests of study by the Institute of Law Research and Reform, public scrutiny and the passage of time, before final enactment as legislation.

What options were open to the body or person recommending changes in our law? The problems to which answers were sought were certainly not in doubt nor did they lack the voices to express them. There were at least four major difficulties, and these were:

(i) The rules" were not representative of a "normal" marital relationship;

(ii) The rules were not primarily designed for a continuing marital relationship;

(iii) The concept of advancement had caused untold difficulties;

(iv) The sociological impact of non-ownership by the wife of family assets had been seriously under-estimated.

Possible solutions seemed almost endless in that the variables included not only the system itself, but also the property subject to it, and the time of the system's operation. Three major options were open, namely:

(i) Community of Property: Under such a system marriage would indeed create a community, but with both parties as equal partners rather than the legal personality of the wife being incorporated into that of the husband, as was the case at common law. ${ }^{12}$ However, the suggestion of a community of property regime is not a solution in itself, since important questions remain in respect of the property to be included. For example, the system might apply to all property, or only to property acquired after the marriage. Some particularly nice questions might revolve around the inclusion or exclusion of interests by way of trust or settlement or gift from a third party.

(ii) Deferred Sharing: A second major option is to defer the operation of any system until the termination of the marriage upon annulment, dissolution or death. At that time the property of the spouses might be subject to a system such as that mentioned in category (i) above, or to a discretionary system based on a number of defined factors. (This, in fact, would not be dissimilar to the option chosen in Family Relief Legislation where the choice between forced share provisions and a discretionary system was exercised in favour of the latter).

10. Can Abr. (2nd) ${ }^{\circ} 1677$ :

Family Arrangements - Natural Love and Affection as Consideration

The impossibility of estimating the value of objects which dictate the actions of parties in entering into family arrangements where the consideration is compounded partly of value and partly of love and affection has led to the exception of family arrangements from th rules as to consideration which affect other kinds of contracts. [Sears v. Hicks (1906) 3 N.B. Eq. 281]

See also: Persse v. Persse 7 C 1 and F. 279; Hoghton v. Hoghton 15 Beav. 278

11. By "rules" here is meant the Common Law rules and the judicially developed exceptions thereto.

12. Blackstones Commentaries, Book 1, c. 15. 
(iii) Limited Remedies on Termination of Marriage: In order to create a redistribution of property on termination of marriage a number of changes would be necessary, not the least of which would be a major change in practice. In effect, to the present remedies of maintenance and support would be added the right to redistribute property. To date, this had been rejected as ultra vires of federal legislation in the divorce field, ${ }^{13}$ not accepted for purposes of the Domestic Relations Act, ${ }^{14}$ and accepted only reluctantly in limited circumstances upon termination of marriage by death. ${ }^{15}$

With each of these categories further questions arise as to whether or not the system should apply to all property, family as opposed to commercial assets, earned as opposed to non-earned assets.

The aim of any legislation dealing with matrimonial property should be to maximize the situations in which the general rules are applicable and to minimize those circumstances which require exceptions. This, indeed, was the stated purpose of the Report prepared by the Institute of Law Research and Reform after that body was requested in 1971 by the Legislature to study the problem. ${ }^{16}$ In order to obtain an informed impression of public attitudes and opinions on the subject of matrimonial property, two tasks were undertaken. Initially, a survey of the ownership of property by married persons, and the attitudes of spouses to that ownership, resulted in a finding that the majority of persons surveyed regarded both spouses, and not merely one of them, as the owners of assets such as house, car and the like. The second task was to issue a Working Paper, together with a questionnaire, designed to elicit views and comments on the matter. The Paper contained a description of the existing regime of separation of property, and outlined three possible alternatives: community of property, deferred sharing and a discretionary division. The majority of those who responded preferred a deferred sharing system to operate upon dissolution of marriage during the lifetime of both spouses. Some were in favour of a discretionary system, while only a few favoured community of property.

The net result of the survey and the Working Paper appeared to indicate a preference for shared property over separation of property and this factor influenced the majority of the Institute Board in their final proposal. A minority on the Board was not convinced that the response to the Working Paper showed a clear comprehension of the practical implications of a deferred sharing system, and therefore doubted whether those responses necessarily supported such a system. ${ }^{17}$ As a result the minority proposed a system of judicial discretion.

The deferred sharing scheme of the majority entailed the application of four general principles: ${ }^{18}$

13. See the judgement of Moir, J. respecting redistribution of property on divorce, in Krause v. Krause [1976] 2 W.W.R. 622

14. Domestic Relations Act, R.S.A. 1970, c. 113, Part 3, ss. 16-26.

15. Re Willan [1951] 4 W.W.R. (N.S.) 114 (Alta. S.C.); Re Lafleur [1948] 2 D.L.R. 682 (Man. K.B.)

16. Report 18, p. 12

17. Id., p. 14

18. Id., p. 35 
(i) During marriage each spouse would be separate as to property;

(ii) Upon dissolution or breakdown of the marriage, each spouse would be entitled to one half of the economic gains made by both during the marriage, unless the contribution of one spouse to the welfare of the spouses and their family was substantially less than might reasonably have been expected under the circumstances;

(iii) The sharing would normally be carried out by a balancing payment which would give each spouse his or her proper share of the economic gains to the couple;

(iv) In arriving at the amount of gains to be shared, the value of property owned by each spouse at the time of the marriage, or received by one of them by gift or inheritance, would not be included, and further, the existence of debts would be taken into consideration.

The system was to apply to parties married after the commencement of Bill Number 7, and to other parties who might acquire a common habitual residence in Alberta after their marriage. ${ }^{19}$ Provision was made, however, for parties to contract out of the deferred sharing system. Otherwise, the system would terminate upon dissolution of marriage by death or divorce, or upon the granting of a judicial separation. ${ }^{20}$ Transitional rules were to apply to parties married before the coming into effect of the legislation, who were living separate and apart at the time. ${ }^{21}$

In what respects would a system of judicial discretion, as proposed by the minority, differ from that described above? Most fundamental was the power of the court to divide the property of husband and wife between them, on principles of fairness and justice, in each particular case. ${ }^{22}$ Furthermore, the power of the court would not be limited to the economic gains made by the parties during marriage, but would be expanded to include property, whenever and however obtained by the parties to the marriage. Such a system would be akin to that introduced in England in 1970, with one major exception; namely, that the English system deals with division of property and with support at the same time. Finally, since each case was to be decided on its own merits and circumstances, a list of mandatory factors was to be considered by the court in making a distribution, including the following: contribution, economic circumstances, duration of marriage, conduct, time and manner of acquisition of property, wrongful disposal of property, previous agreements, dispositions and legal proceedings.

Neither system is perfect, nor without merit, and the report made mention of the comparative advantages and disadvantages. ${ }^{23}$ The system of judicial discretion was said to be simpler in expression and application, while the deferred sharing system could lead to misunderstanding and litigation. Further, the system of discretion, not bound by prescribed rules, would be more flexible, allow more "tailor-made" decisions, and allow the court to distinguish between the deserving and the undeserving. The English system was a model of judicial discretion, at least in the eyes of the Minority Report.

$\begin{array}{ll}\text { 19. } & \text { Id., p. } 157 \\ \text { 20. } & \text { Id., p. } 159 \\ \text { 21. } & \text { Id., p. } 170 \\ \text { 22. } & \text { Id., p. } 118 \\ \text { 23. } & \text { Id., pp. } 26-28\end{array}$ 
On the other hand, a discretionary system is necessarily more uncertain, due to the absence of prescribed rules. The majority felt that a discretionary system would not give adequate consideration to the right of a spouse to share in the economic gains, as opposed to the right of a spouse to apply to the court for a share of those gains. In addition, it was suggested that a discretionary system, emphasizing as it would individual cases, would make access to, and understanding of, the principles of judicial discretion as applied to matrimonial property distribution, comparatively more difficult. It would be preferable, the majority suggested, and less fruitful of litigation, to state the rules statutorily than to allow them to be developed by judicial decision. On a more practical plane, it was suggested that forecasting and negotiation of settlements would be more difficult under a discretionary system and that, in any event, the same process of evaluation of property and rights to it would be adhered to under a discretionary system, yet without the guidance of rules laid down by statute.

Problems attendant on the rights to and in the matrimonial home were dealt with separately by the Institute. ${ }^{24}$ Two alternatives presented themselves: one, altering the law so that a husband and wife would automatically become co-owners of their matrimonial home, whether the home was acquired by either or both of them or, two, allowing the matrimonial home to be dealt with as a general asset under the property regime, whichever was chosen, without any special rules. Based on the unfavourable response to the idea of co-ownership, the Institute decided against the former alternative. Instead, it was anticipated ${ }^{25}$ that either of the two systems proposed would provide most of the benefits conferred by coownership, while eliminating cases where co-ownership would operate unfairly, and, at the same time, obviating the necessity for complicated exceptions designed to benefit a comparative few. Both systems would allow the value of the matrimonial home to be taken into account, and, further, the court could direct the transfer or possesion of the home to one spouse.

Together with either of these systems, the Institute recommended ${ }^{26}$ that the court be given an additional discretionary power to make the matrimonial home, and the household goods and chattels, available for the exclusive use of one spouse on an interlocutory basis, or for an indefinite or fixed period of time. In the light of the effect of the jus accrescendi in a joint tenancy, it was suggested that the court be empowered to convert such a tenancy into a tenancy in common, such an order to be registerable with the Land Titles Office and effective when so registered. ${ }^{27}$ These same powers regarding the matrimonial home were to apply equally where the parties were tenants and not owners of the property. (The Dower Act was regarded as an adjunct to support and no recommendation was made for its repeal. $)^{28}$

Upon receiving the recommendations contained in the Institute's Report, the Legislature proposed Bill 102 and Bill 103 in the Third Session of the 18th Legislature, being entitled respectively "The Matrimonial Property

24. Id., p. 137

25. Id., p. 139

26. Id., p. 142

27. Id., p. 143

28. Id., p. 144 
Act" and "The Matrimonial Home Possession Act". The former "Act" declined to follow the recommendations of the Majority Report and, for the most part, paraphrased Bill 2, proposed by the Minority Report. On the other hand, the latter "Act", although including the Institute's Bill 3, went further. Not satisfied with the Dower Act definition of "homestead", the terms "household goods" and "matrimonial home" were carefully defined, the definition of "household goods" being strikingly similar to that contained in the Ontario Family Law Reform Act. Indeed, section 3 dealt at length with the property which could be the subject of an order under the Act, and included the right to direct the restraining or eviction of a spouse from the home.

The two Bills were allowed to die on Order Paper, with the promise that, after a suitable time for public reaction and comment, the Bill, as amended, would be reintroduced at a future session. As a result, the Matrimonial Property Act (Bill 20) was introduced and was assented to on May 16th, 1978. The Act was to come into force on a date to be fixed by proclamation, later fixed as January 1st, 1979. A number of cosmetic changes were made to the original Bills, not the least of which was the incorporation of the two original Bills as separate parts of a common Act. More significant was the change brought about in the system itself. In effect, the two alternatives were combined: the court may depart from a presumption of equal sharing (deferred sharing) where a purview of a number of factors (a discretionary system) makes it appropriate to do so. It may be argued that the flexibility of discretion is retained while the certainty of prescribed rules is added. However, it may also be argued, and, it is submitted, with equal force, that the discretion is hampered by so-called "rules" which are themselves lacking in any certainty. Indeed, what was touted ${ }^{20}$ as a presumption of equality is, in fact, merely a weak presumption applicable to a limited part of matrimonial property..$^{30}$

\section{LIMITS OF THE COURT'S JURISDICTION}

It is to be noted that the Act is premised on the concept of marriage breakdown. ${ }^{31}$ There is no possibility of dividing property under this Act between spouses who are living together, happily or otherwise, unless there are grounds for divorce or one spouse is dissipating his or her property to the detriment of the other.

The important factors therefore are twofold: first the fact, and second the time, of the marriage breakdown. To invoke the jurisdiction of the court, the parties and the marriage must have some connection with Alberta at the appropriate time, which may be either at the time of the marriage or upon the breakup of the parties. ${ }^{32}$ One must always keep in mind that an action under Part 1 of the Act can be brought concurrently with or subsequent to the issuance of a Petition for Divorce. ${ }^{33}$ However, invoking jurisdiction on this basis is simply invoking it at the time of marriage breakdown. The differing factor is that the concept of residence, which will be discussed below, is not necessarily present. ${ }^{.44}$

29. See Foster's speech, in Alberta Hansard, Monday, May 15, 1978 [18 Legisl., 4th Session, n. 48,1223 ]

30. See, for example, the exceptions in sections 7(2) and (3).

31. See section 5(1)(a) to (e)

32. See section 3(1)

33. See section 3(2)

34. Compare section 3(1) with section 5(1), Divorce Act, R.S.C. 1970, c. D-8 


\section{A. Jurisdiction (Where)}

Under section 3(1) of the Act, it is necessary that:

a) the parties be habitually resident in Alberta at the time they bring the action; or

b) Alberta was the last joint habitual residence of the parties; or

c) in cases where the parties have not ever established a joint habitual residence since their marriage, they did have a common habitual residence in Alberta at the time of the marriage.

The concept of habitual residence, although referred to peripherally in Canada in such statutes as the Federal Elections Act, ${ }^{36}$ was primarily developed in discussions at the Hague in an endeavor to reach an acceptable compromise between the civil law and common law systems of Europe. Definitions have been difficult to find, but the Hague definition should guide our course to some extent, especially since it has been expressly adopted by several statutes in England.

Perhaps the most authoritative statement is the definition quoted by Professor A. E. Anton: ${ }^{36}$

In determining whether a residence is habitual, account is to be taken of the duration and the continuity of the residence as well as other facts of a personal or professional nature which point to durable ties between a person and his residence.

The voluntary establishment of a residence and a person's intention to maintain it are not conditions of the existence of a residence or a habitual residence, but a person's intentions may be taken into account in determining whether he possesses a residence or the character of that residence.

This particular concept has been applied, by implication, in Cruse v. Chittum. ${ }^{37}$ The essential elements of the concept contained in the SubCommittee's recommendations were accepted and should, it is suggested, be regarded as representative of the modern approach to the concept of habitual residence.

On the one occasion in which the term "habitual residence" was dealt with in Canada, Rouleau J. (In Re Banff Election, Brett v.Sifton ${ }^{38}$ ) said at p. 145: "the word 'habitual' in the definition of residence does not mean the presence in a place either for a long or short time, but the presence there for the greater part of the period, whatever that period may be (whether ten years or ten days) referred to in each particular case". This would seem to be contrary to the Hague citation and perhaps it would be more useful if "habitual" were given its dictionary meaning. In that sense it should denote something "in the nature of a habit" or "customary" which is the kind of continuing connection desired for the purposes of jurisdiction. Indeed, it is felt that the quality of the connection is much more important than the quantity. The consensus of opinion appears to be that habitual residence is equivalent to the concept of domicile, shorn for the most part of its intricacies and technicalities. The intricacies of domicile still are with us, with the exception of jurisdiction on divorce; the wife now may, indeed must, under section 5(1) of the Divorce Act (Canada) acquire her own domicile independently on that of her husband. ${ }^{39}$

35. Territories Election Ordinance, C.0. 1898, c. 3, s. 39

36. (1969) 18 I.C.L.Q. pp. 629-630, footnote 24, quoting from the Draft Recommendations of the Council of Europe's Sub-Committee on Fundamental Legal Concepts.

37. [1974] 2 All E.R. 940

38. (1899) 4 Terr. L.R. 140, per Rouleau, J. at 145

39. Jablonowski v. Jablonowski [1972] 3 O.R. 410 
Under the present drafting of section 3(1) of the Matrimonial Property Act, parties are bound together in habitual residence; either joint or common.

At first blush, section 3(1) of the Act seems to enlarge the jurisdiction of the court. However, on careful analysis one might well conclude that the jurisdiction of the courts with respect to an application under this Act are in fact narrowed when compared with other types of action.

Looking at the individual parts of section 3(1):

a) if the habitual residence of both spouses is Alberta, whether or not they are living together, the court can take jurisdiction. This would seem to preclude an application by one party where the other is not living in Alberta. In a divorce action, assuming domicile of the Petitioner, the residence of either party, for the one year period, would give the court jurisdiction. ${ }^{40}$

b) either spouse may bring an action if their last joint habitual residence was Alberta. This looks reasonable at first inspection, but really harkens back to the 1930 Federal Divorce Jurisdiction Act ${ }^{41}$ wherein a deserted wife was allowed to bring an action for divorce two years and upwards after her desertion in the jurisdiction in which she was then resident. (She could not obtain her own domicile at that time.) This subsection would cover the deserted spouse, who was deserted in Alberta, provided the last joint habitual residence was in fact in Alberta. This would not allow an application to be brought by a person who returned to Alberta after having lived somewhere else and having been deserted in that jurisdiction.

c) if the spouses did not establish a joint habitual residence since their marriage but they had a common habitual residence at the time of the marriage the court can take jurisdiction. The difficulty with this particular subsection is that it strains one's imagination to attempt to conjure up a fact situation applicable. If the parties married, and they would have to marry while each of them was habitually resident in Alberta (but not necessarily marry in Alberta), they could not have lived together in this Province or else they would have established a joint habitual residence. Does this mean that they would have travelled immediately upon their marriage? Or one of the spouses immediately went to jail? Or that it was a marriage for immigration purposes? Or did somebody in legislative caucus just happen to read about the non-cohabitation clauses as contained in the Ontario Family Law Reform Act?'2

The above discussion concerning section $3(1)$ is really academic in that most of the actions commenced under Part 1 will use, as their basis of jurisdiction, section 3(2), the commencement of Petition for Divorce. This of course is a jurisdictional factor over which the Provincial Legislature has absolutely no control. The commencement of a divorce action as the basis for jurisdiction would seem to be eminently logical as it would be contemporaneous with the marriage breakdown. Indeed it may be negligent

40. See Divorce Act, R.S.C. 1970, c. D-8, ss. 5(1)(b) and (c).

41. Federal Divorce Jurisdiction Act, S.C. 1930, c. 15, repealed by the Divorce Act (1968)

42. See Family Law Reform Act, S.0. 1978, c. 2, s. 4(1). 
on the part of a lawyer not to commence a matrimonial property action along with a divorce action, bearing in mind the broader powers of distribution of property available under this Act, contrasted with the limited powers of the court to award lump sum maintenance under the Divorce Act. If one were simply to commence a matrimonial property action without a divorce action it would have to be done for some obscure strategic purpose. One must also keep in mind the provisions of section 17(2) wherein the court may adjourn an application under Part 1 to accommodate the bringing of a Petition for Divorce by the other spouse, or settlement of other property disputes.

\section{B. Time Limits (When)}

The time limits within which an application may be brought are set out in sections 5 and 6 of the Act. Section 5 defines marriage breakdown and the declaration of marriage breakdown while section 6 states that the 2 year period within which an application may be brought runs from the time of breakdown or declaration of breakdown as previously defined in section 5 . The application should be commenced upon, or within two years of, the fact of breakdown or a declaration of breakdown as defined by the Act.

The three circumstances in which the court may declare a marriage breakdown are set out in sections 5(1)(a) and 5(1)(b). These circumstances are the granting of a Decree Nisi of a divorce, a Declaration of Nullity of Marriage, or a Judgement of Judicial Separation. A question may be raised as to whether or not the phrase "a Declaration of Nullity of Marriage" is intended to be a term of art and further, whether or not a Decree Nisi of Annulment of Marriage is included in that phrase. On a strict interpretation of the language the term a "Declaration of Nullity" would not apply to a situation where a voidable marriage is annulled; probably however, it is merely a drafting error and the phrase is intended to apply to any judgement which declares a marriage null and void $a b$ initio or annuls it retroactively. ${ }^{43}$

For the purpose of determining when the periods set out in section 6 would commence, attention must be drawn to Rule $322^{44}$ which states that a judgment, unless otherwise specified by the court, shall be deemed to take effect from the date of pronouncement, despite the fact that filing and/or service of judgment may have taken place at a later date.

Section 5 further defines marriage breakdown in sub-section (1)(c)and subsections (3) and (4). Primarily, a breakdown is deemed to have occurred where the parties have been living separate and apart for at least one year immediately prior to the commencement of the application or for a period of less than one year immediately prior to the commencement of the application if there is no possibility of reconciliation. There are then three major questions which must be asked in relation to section 5(1)(c) relating to the determination of what constitutes "separate and apart," the time for which such a status must have existed, and the effect of any attempts at reconciliation during that time.

The phrase "separate and apart" has been used previously in the Divorce Act, ${ }^{45}$ and there is voluminous case law to guide the reader in determining

43. DeRenneville v. DeReneville [1948] P. 100 at 110

44. Alberta Rules of Court, R. 322

45. Section 4(1) (e) 
whether parties are living "separate and apart". ${ }^{46}$ The phrase has been the subject of judicial comment to the effect that it must be viewed disjunctively and means more than mere geographic separation. ${ }^{47}$ Numerous cases have supported the proposition that the parties may be deemed to be living separate and apart where they are still living under the same roof. One of the critical factors in such cases appears to be whether or not the parties are performing household services for one another without payment. ${ }^{48}$ Under the Divorce Act this critical factor would tend to support the proposition that parties living under the same roof cannot be "said to be living separate and apart" where some household services are being provided. ${ }^{40}$ This line of cases $^{\text {so }}$ is specifically amended, for purposes of the Matrimonial Property Act, by section 5(3) which states that "spouses may be held to be living separate and apart notwithstanding that they have continued to reside in the same residence or that either spouse has rendered some household service to the other during the period of separation". ${ }^{31}$

A breakdown will have occurred, within the meaning of the Act,when the fact of living separate and apart has subsisted for a period of at least one year immediately prior to the commencement of the application. ${ }^{62}$ This time frame, and the way in which it is described by the Statute, is similar to that required for residence purposes under the Divorce Act. Perhaps the most important aspect of this requirement is that the period must have subsisted and be subsisting immediately prior to the commencement of the application.

A central requirement in the finding of marriage breakdown appears to be the impossibility of reconciliation. ${ }^{63}$ Its importance cannot be underestimated, as evidenced by the provisions of section 5(1) (c) (ii), wherein the period of one year may be shortened if, in the opinion of the court, there is no possibility of reconciliation of the spouses. It might be important that the spouse who insists there is no possibility of reconciliation also be the applicant under the Act. No better evidence could be shown of the impossibility of reconciliation than the necessity of bringing an application under the Act. However, the possible resumption of cohabitation for purposes of reconciliation may also have other effects under the Act.

46. Galbraith v. Galbraith (1971)1 R.F.L. 77;Rousell v.Rousell (1971) 1 R.F.L. 227; Compton v. Compton (1971) 1 R.F.L. 229; Dimaggio v. Dimaggio (1972) 4 R.F.L. 3; Lachman v. Lachman (1971) 2 R.F.L. 214

47. Galbraith v. Galbraith, supra n. 47; Rousell v. Rousell, supra n. 47

48. Reid v. Reid (1971) 1 R.F.L. 229 at 229:

In spite of that chasm between the parties, the situation remained that of a single household in which the food eaten by the husband at breakfast was purchased by the wife, and in which she performed for him at least the service of doing his personal laun. dry. Unlike the spouses in the Rushton case the parties were not compelled by economic considerations to carry on in this half-way situation.

49. Rushton v. Rushton (1968) I R.F.L. 215

50. Supra, n. 47

51. Presumably the other factors such as separate bedrooms, and no mutual social activity would still be significant.

52. Sections 5(1)(c)(i) and (ii)

53. It is probable that the possibility of reconciliation may be raised by either party. Some question may be raised as to whether the Court may consider this issue on its own initiative, in the absence of a specific duty to do 80. Contrast the Divorce Act, R.S.C. 1970, c. D-8, s. 59(1)(d), and the specific duties set out there. 
A single period of resumption of cohabitation, with reconciliation as its primary purpose, will not preclude the spouses from arguing that they are nevertheless living separate and apart (s.5(4)). Considering the treatment afforded to similar provisions under the Divorce Act, ${ }^{54}$ it might be naive to suggest that the wording of section 5(4) is perfectly clear. However, one might be permitted to suggest that the exception be interpreted strictly so as to mean not more than one period, which does not subsist for longer than 90 days, together with the requirement that reconciliation be its primary purpose. Thus, a resumption of cohabitation on more than one occasion, or for a period longer than 90 days, or for a purpose other than reconciliation, would disallow the application under section 5(4). In any one of these three situations, the parties could not be considered to be living separate and apart for a period of at least one year immediately prior to the commencement of the application. Such a one year period would have to be re-established before an application can be brought. Perhaps the relevance of section 5(1)(c)(ii) is that it could be applicable to a situation where the parties have attempted reconciliation but do not come within the provisions of section 5(4), and are again living separate and apart. A further, and more significant difference between the provisions of the Divorce Act and the provisions of the Matrimonial Property Act relates to the effect of a period of resumption of cohabitation for purposes of reconciliation. Under the Divorce Act, the period, if regarded as purely for the purposes of reconciliation, would not be included at all, and would be ignored for purposes of establishing that the spouses are living separate and apart..$^{55}$ Under section 5(4) of the Matrimonial Property Act the effect of a single period of resumption of cohabitation is that the one year period required in section 5(1)(c)(i) would be interrupted and would not commence to run again until the period of resumption of cohabitation was discontinued. Thus, for example, parties who separate April 1st, and who resume cohabitation during the months of January and February of the following year, would not, under the wording of section 5(4), have been living separate and apart for a period of one year until July 1st of that following year. Under the Divorce Act, the resumption of cohabitation during the months of January and February would be entirely ignored and the parties would have been living separate and apart for one year on April 1st of that following year.

54. See the differing interpretations of section 9(3)(b) and the section 2 definition of "condonation" in the following cases:

a. the "plain" view: One period only, of no greater than 90 days: Busch v. Busch [1973] 3 W.W.R. 402

b. any number of periods, not greater than $\mathbf{9 0}$ days in the aggregate

c. any number of periods, provided none is longer than 90 days: Lavallee v. Lavallee [1975] 17 R.F.L. 91, approved in Crawford v. Crawford [1976] 3 W.W.R. 767

55. The exact wording of Divorce Act, R.S.C. 1970, c. D-8, s. 2 is:

"condonation" does not include the continuation or resumption of cohabitation during any single period of not more than ninety days, where such cohabitation is continued or resumed with reconciliation as its primary purpose;"

also: Section 9(3)(b): "For the purposes of para. 4(1)(e), a period during which a husband and wife have been living separate and apart shall not be considered to have been interrupted or terminated

(b) by reason only that there has been a resumption of cohabitation by the spouses during a single period of not more than ninety days with reconciliation as its primary purpose." 
The third circumstance in which the court may be required to act is provided for in section 5(1)(e), where the parties are living separate and apart and one party is dissipating property to the detriment to the other spouse. Further provisions are included in section 5(1)(d) which allow the court to act to prevent a substantial transfer of property to a person other than a bona fide purchaser, or to a donee, where the transfer is to take place or has taken place with the intention of defeating a claim under the Act.

The time limit within which an application may be brought, will commence to run upon the happening of one of the three events described above, namely, the declaration of marriage breakdown, the fact of marriage breakdown, or the activity which defeats the claim under the Act. The primary rule is that an application be commenced within two years after separation ${ }^{66}$ However, this rule is displaced where the action is commenced in conjunction with a Petition for Divorce, or a request for a Declaration of Nullity or Judgment of Judicial Separation, in which case the application should be commenced within two years thereafter ${ }^{57}$ With respect to the activity which defeats a claim under the Act, the application must be commenced within one year after the date when the property is transferred or given, or within two years after the separation, whichever first occurs. ${ }^{58}$ The addition of the phrase, "whichever first occurs" is entirely confusing and totally lacking in any rationale. It would appear that as a result of this additional phrase, a transfer of property with intent to defeat a claim under the Act, which takes place more than two years after the date of separation of the parties, is entirely beyond the purview of the court. The basic period of two years, within which an action must be commenced, is extended in section 6(1) where the applicant commences an action for divorce, nullity of judicial separation. However, section 6(3) does not provide for an extension of the two year period where the party wishes to preserve property which would otherwise be transferred or given away with the intention of defeating an application under the Act. It seems somewhat strange and inconsistent to allow the two year period to be extended in one case and not in another. Further, it also seems more than a little unusual to set up a basic two year period to run from the time of separation, when the majority of cases are likely to be in conjunction with divorce which may or may not be within two years after separation. That being the case, there seems to be little or no reason for the inclusion of section 6(2). Similarly, if that be the case, there seems to be little or no logic to the refusal to extend the two year period in section 6(3).

At this stage, the attention of the reader should be drawn to the provisions of section 11 which may impose a further time limitation. In this section provision is made for the possibility of an application being brought by the surviving spouse of a deceased person. The conditions attaching to such an application are that the surviving spouse has commenced, or would have been able to commence, an action prior to the death of the spouse. In other words, the surviving spouse must have been able to place himself or herself within the provisions of section 5 , and within the two year time limit as set

56. Section 6(2)

57. Section 6(1)

58. Section 6(3) 
out in section 6 . If so, then an application by a surviving spouse, consistent with other provisions which require claims to be made against an estate within six months after the death ${ }^{50}$ must be brought within six months after the date of issue of a grant of probate or letters of administration of the estate of the deceased person. Some question may be raised as to whether or not the six month limitation period in section 11 might alter a two year limitation period which would otherwise be applicable under section 6. The provisions of section 11 would probably take over from the provisions of section 6 and operate either to reduce or to extend the two year limitation period applicable prior to the death of the spouse.

There appears to be a lacuna in the Act, upon closer examination, that no general provision is made for the possibility of fraud or the concealment of property with respect to claims under the Act. Perhaps the unfortunate applicant who has not been privy to attempts to defeat the Act, as one might expect, could garner some assistance from the provisions of the Limitation of Actions Act which prevents the limitation period from commencing until such time as the person who might take action is aware of the fact that he is able to take action. ${ }^{60}$ While there are specific provisions dealing with situations where the applicant might need to act quickly or might be entitled to gain information as to the property holdings of the other party, these are inadequate, it is suggested, to deal with the area of fraudulent concealment generally. It would hardly be reasonable to conclude that an applicant is adequately protected by the right of discovery as provided by the Act $^{61}$ and the provisions of section 5 allowing the applicant to take action in respect of the spouse who has shown an intention to make a substantial gift to a third party or to transfer to a non bona fide purchaser for value so as to defeat a claim under the Act. The onus of proof itself in those subsections $^{62}$ might be sufficient to discourage any potential applicant in such circumstances.

\section{The Applicant (By Whom)}

No exhaustive definition is contained in the Act as to who is entitled to bring an application for a matrimonial property order. However, by implication, the wording of section 3 must limit the applicant to a spouse in a legally valid marriage. The opening words of section 3 are "a spouse may apply to the court...". Several definitions are available which would elucidate the status of a spouse and these are for example:

1. "One's wife or husband" (Black's Law Dictionary)

2. "A married woman in relation to her husband" or

3. "A married man in relation to his wife" (Oxford English Dictionary) It would seem clear that the word spouse relates to a person who enjoys the status of being party to a valid subsisting marriage. Initially then, the applicant must be a person who can show that there was a valid marriage which satisfied the requirements of capacity, formal validity, the nature of the

59. See for example Family Relief Act, R.S.A. 1970, c. 134, s. 16

60. Limitation of Actions Act, R.S.A. 1970, c. 209, s. 57

61. Section 31

62. Sections $5(1)(d)$ and (e) 
marriage relationship as defined in $H y d e$ vs. $H_{y d e},^{63}$ and the requirement that the marriage be heterosexual. ${ }^{64}$

Judicial development has extended the meaning of spouse to confer certain rights on parties to void or voidable marriages. However, despite the fact that statutes ${ }^{65}$ have conferred the right to maintenance for example, upon the parties to a void or voidable marriage, the common law jurisprudence has insisted that proprietary rights be conferred or exercised only where the party was acting in good faith. (Re Eaves ${ }^{66} \mathrm{Re}$ Dewhirst). ${ }^{67}$

The extended definition in section 1(e) as qualified by section 2 would appear to be aimed at two particular purposes. The first is necessary because of the time limits imposed in the act. If the question of whether or not a person was a spouse were to be viewed strictly as a matter of status, that status would terminate after the issue of a Decree Absolute of divorce. Thus, for example, in order to allow a person to bring an application within two years after divorce, section 1(e) extends the definition of spouse to include a former spouse. It must be assumed that this inclusion is intended to apply only within the specified time limits in section 6 . The second purpose would appear to bring the statute into line with the existing case law ${ }^{68}$ which would allow the parties to a purported marriage to exercise certain rights. Section 2 also echoes the case law position ${ }^{68}$ by insisting that the party to a purported marriage, which is in fact void, cannot exercise any rights under the Act if he cannot show good faith. A person will be presumed to be incapable of showing good faith if he or she knew, or had reason to believe, at the time of marriage, that the marriage was void.

\section{Methods of Instigating Court Adjudication (How)}

The method of application is succinctly stated in section 4 to the effect that an application shall be commenced by Statement of Claim. This of course applies only to Part 1 and the method of application in Part 2, set out in section 30 , will be dealt with below under the section dealing with matrimonial home possession.

One should not leave section 4 , however, without drawing attention to the mandatory nature of the wording of the section. Had the wording been "may be commenced", the curative provisions of the Rules of Court, ${ }^{70}$ specifying that an action commenced in an irregular mode is an irregularity only and not a nullity, would have been applicable. However, the mandatory nature of the wording in this section may well preclude the application of those curative rules.

63. Hyde v. Hyde [1861-73] All E.R. 175

64. See, generally: Ch. 2, "The Nature of Marriage", Bromley's Family Law, (4th ed. 1971)

65. The Domestic Relations Act, R.S.A. 1970, c. 13, Part 3; The Legitimacy Act, R.S.A. 1970,c. 205, 88. 3 and 4.

66. [1939]4 All E.R. 260.

67. [1948] 1 Ch. 198

68. Id., Re Eaves, supra n. 67

69. Id., and the Legitimacy Act, R.S.A. 1970, c. 205, ss. 3 and 4.

70. Alberta Rules of Court, Part 43, nos. 558-561 
Once again, section 17 raises its ugly head. One is hard pressed to find a rationale or an opportunity for the application of section 17(1), but some explanation must be attempted. The purpose of the first subsection would appear to be automatically to raise the issues in Part 1 of the Matrimonial Property Act in any other matrimonial cause in which a question respecting property arises between the spouses. This clearly sets forth a two-fold test requiring:

1. A matrimonial cause, and

2. A question respecting property between the spouses.

The former phrase, "a matrimonial cause", has been defined as follows:

1. Injuries respecting the rights of marriage, jactitation of marriage, restitution of conjugal rights, divorces and suits for alimony. ${ }^{71}$

2. Divorce, nullity, judicial separation, jactitation of marriage, restitution of conjugal rights. ${ }^{72}$

3. Divorce, nullity of marriage, judicial separation, jactitation of marriage, or restitution of conjugal rights. ${ }^{73}$

The rub appears to be that a matrimonial cause, other than the action for damages against a paramour, is extremely unlikely to involve a question respecting property between the spouses. For example, under The Divorce Act, the court's jurisdiction is limited to the awarding of maintenance, either lump or periodic, and an order requiring security for such maintenance ordered. ${ }^{74}$ On the other hand, the action for damages against a paramour is hardly likely to be an action between the spouses. The end result is that the situations in which section $17(1)$ might be applicable are extremely rare. At best, s.17(1) might be confined to sections 23 and 24 of the Domestic Relations Act dealing with the settlement of property belonging to an adulterous spouse on the innocent spouse or children of the marriage, and variation of ante-nuptial or post-nuptial settlements, respectively.

\section{ANCILLARY REMEDIES}

Upon commencement of an action under the Matrimonial Property Act certain obligations and rights arise. These are described in Part 3 of the Act, the general part. The obligations are referred to in section 31 , which requires each spouse to file with the court and to serve on the other spouse a disclosure of the particulars of the property owned by that spouse, whether or not it is situated in Alberta. This is also to include, by virtue of section 31(2), any property that was held by a spouse at any time within a one year period prior to the commencement of the application. Further, ${ }^{75}$ any person is prohibited from disposing of or encumbering household goods, or removing them from the matrimonial home, without a court order or the consent of both spouses. This prohibition is fortified by the attaching of summary conviction remedies. ${ }^{78}$

71. Black's Law Dictionary

72. 12 Halsbury's Laws (3d) 213,4391 . (There is also a suggestion that this may include an ac. tion to recover damages from the paramour of an adulterous spouse: See Jacks v. Jacks and Wilks [1961] 1 All E.R. 251).

73. Words and Phrases Legally Defined, Vol. III, 1-N

74. See sections 10,11 and 12.

75. Section 33

76. Section 33(2) 
The spouse, in accordance with section 34 , has the right to bring an application, either in the original action or summarily by Originating Notice of Motion, with notice or ex parte, for an order preventing the gift or sale of property if that gift or sale might defeat a claim by the other spouse under the Act.

A further right conferred by section 35 is the possibility of filing a Certificate of Lis Pendens with the Registrar of Land Titles. It should be noted that this right is limited to the spouse who commences the proceedings, and it would appear that the respondent in such an action might well be precluded from filing a Lis Pendens under section 35 . This of course would not be the case if the defendant were to file a counter-claim, which would constitute the commencement of an action.

\section{PROPERTY GOVERNED BY THE ACT}

One of the crucial questions in any matrimonial property regime is the determination of the property which is to be subject to the regime. Some comment has already been directed ${ }^{77}$ to the possible lines of demarcation between private and commercial assets, earned and non earned assets. Acceptance of any one of these distinctions calls for precise drafting and definitions. The Ontario legislation wil obviously prompt, as it has already, some nice questions as to the precise meaning of "ordinarily used or enjoyed by both spouses or their children." 78

Given the title of the Alberta legislation, and the importance of this matter to the working of the legislation, one might expect to find some mention of the "matrimonial property" in the definition section. Such an expectation would, however, not be fulfilled. Nor would it be fruitful to search for a comprehensive definition anywhere else in the statute.

The closest one would come is the wording of section 7(1), which provides that the court may distribute "... all the property owned by both spouses and by each of them". The only warning as to the inadequacy of the definition is the phrase "in accordance with this section" which, far from being innocuous or superfluous, should warn the reader that there is more to come.

However, despite the importance to be attached to section 7(1), for what it does say, there are a number of other points which should not be overlooked. It is clear that the Alberta legislation has eschewed any attempt to segregrate family assets from any other type of asset. The sine qua non of the section is ownership, not the type of asset nor the use of it by one or both parties, but the fact of ownership. The court cannot distribute property if it is not owned by the parties or one of them. It matters not whether the property is owned jointly, or in common, or by one of the parties indivually, or jointly or in common with a third party; the fact of ownership brings the assets within section 7(1). A major advantage of such an approach is the absence of any necessity to define the way in which property is held. The provisions of the Ontario statute ${ }^{70}$ stipulating that property held by a corporation (where the property, if held by an indivual, would be a "family asset") is to be includ-

77. Supra, p. 375

78. Family Law Reform Act, S.O. 1978, c. 2, s. 3(b)

79. Id., 8. 3(b)(ii) 
ed as matrimonial property have no counterpart in the Alberta statute. Ownership of the property or an interest in the entity which controls the property, combined with the extensive powers of the court under section $9{ }^{80}$ would allow the court to deal with the interest in whatever light it saw fit. One would hope, however, that the classification of property as a business asset would not be unimportant and might be considered a "fact or circumstance that is relevant".

By implication, the wording of section 7(1) must be taken to include ownership at the date of the application under Part 1 of the Act, or within one year prior thereto. The operative portion of the combination must, however, be the ownership at the date of the application, since the recapture provisions of section 10 would appear to apply to only the most obvious and clumsy mala fide transactions. ${ }^{\mathrm{B}}$

The meaning of "matrimonial property", therefore, is deceptively simple: any property, of every nature and kind and wheresoever situate (to borrow a phrase from elsewhere), provided one spouse has a legal or equitable interest in the property, or in the entity which controls the property, or any such property owned within one year of the date of the application, if the conditions in section 10 are applicable.

It would not be remarkable if that were all that should be said about the definition of property subject to a discretionary system. Indeed, the discretion and the factors on which the discretion was to be exercised, would merely assume greater significance. Nor would it be exceptional, in the light of the system chosen in Alberta, for all property to be subject to a presumption of equality, unless the court's discretion requires a different distribution.

The results of section 7, and the effects of the section on the general scheme of the Act are important. All too often, either because of sheer ignorance or shoddy thinking, matrimonial property is said to be subject to a presumption of equality between spouses. By contrast, section 7 creates three categories of property, only one of which is subject to such a presumption. The categories are:-

(i) Exempt Property: The market value of property at the date of the marriage or acquisition, whichever is later, is exempt from distribution under the section if the property is: $:^{83}$
(a) a gift from a third party;
(b) acquired by inheritance;
(c) acquired before marriage;
(d) damages in tort;
(e) non-property insurance proceeds.

(ii) Distributable Property: The court shall distribute, having regard to the factors outlined in section 8 , but without regard to any presumption of equality:

80. Infra, p. 405 under the heading "Powers of the Court".

81. Section $8(m)$. Certainly the business entity would want to take steps to ensure that its assets do not become embroiled in a dispute which would adversely affect the enterprise.

82. Presumably, the requirements of paragraphs (a) to (d) of Section 10 are cumulative, though only one conjunctive or disjunctive word appears between the four paragraphs.

83. Section 7(2) 
(a) the incremental value of property exempt under subsection 2;

(b) property acquired with income from exempt property;

(c) property acquired after Decree Nisi of divorce, annulment or judicial separation (within the time limits);

(d) interspousal gifts;

The distribution is to be in such manner as the court considers just and equitable.

(iii) Divisible Property: Property defined in subsection (1), and not dealt with in subsections (2) or (3) is to be distributed equally between the spouses, unless, having regard to the factors set out in section 8 , it would not be just and equitable to do so.

A final point of note with respect to this section is that it is in no way restricted to property the situs of which is Alberta. The court is empowered by section 9 to frame its order in such a way that the property situated in Alberta is dealt with as part of a global distribution, whether or not the Alberta courts would otherwise have jurisdiction to deal with the nonAlberta property.

Unfortunately, any hope for a simple, effective, uncluttered definition of the property subject to the Act is dispelled by the exceptions set out in subsection (2). The exception contained in subsection (2)(c) would appear to drive a "coach and four" through the definition. Not only must the property be owned by one or both spouses, but the ownership must have been acquired at the appropriate time, that is, after the marriage and not before it, otherwise the property will be exempt. Furthermore, there may be real difficulties after the termination of the marriage. It has already been pointed out $^{\text {84 }}$ that an application under this Act may be made within two years after the Decree dissolving the marriage, and that the provisions of section 10 , supported by the wording of section 31 with respect to disclosures, suggest that the time of the application is the effective date for determining what property may be subject to an order. However, any property acquired after the Decree Absolute and before the application under this Act, would not be property "acquired by a spouse during the marriage" in terms of section 7(4), the subsection which mandates the distribution by the court. There is a specific saving clause with respect to such property, in section 7(3)(c). As will be shown, infra, such property falls into a different category. A further lacuna and one which may be of significance, is that in a void marriage, and/or in a relationship of cohabitation falling short of a valid common law marriage in its proper sense, ${ }^{85}$ there may be no point in an application under the Act. Even though the applicant may come within the extended definition of "spouse" in section 1(e), there may well be no property which can be the subject of an order, in that there is no marriage during which the property can be alleged to have been acquired. ${ }^{86}$ It should be noted in this context that the wording of section 2 is negative in the sense that it specifically declines to confer rights on a party who was aware

84. Supra, p. 381 (under Time for Application)

85. See the classic definition of Dysart, J. in Blanchett v. Hansell [1943] 3 W.W.R. 275

86. The concept of "putative marriage" may be of some assistance in the first situation, but would be of no use in the second. 
that a marriage was void. The section does not, however, expressly confer rights on the party who was not so aware. ${ }^{87}$

Two further exceptions appear somewhat out of place after the wording of section 7(1). Section 7(2)(d) exempts from the operation of the Act an award or settlement for damages in tort in favour of a spouse, and section $7(2)(e)$ exempts the proceeds of an insurance policy that is not insurance in respect of property, unless the award or the proceeds respectively are compensation for a loss to both spouses. At first blush these two paragraphs may have in common the fact that each deals with a peculiarly personal asset, a loss suffered uniquely by one spouse. If that be the case, however, the fact that the asset is acquired in one or the other form should not distinguish it from a peculiarly personal asset which would normally be subject to an order under the Act. An award of damages including special damages for loss of income and general damages for loss of earning capacity would not be in compensation for a loss to both spouses, even though the effects of such an injury might have a significant effect on family welfare and finances. ${ }^{88}$ An endowment policy of insurance is neither a peculiarly personal asset, nor in respect of property, nor in compensation for a loss to both spouses. It is difficult to determine any rationale for these exceptions other than that the form of payment, by damage award or proceeds of insurance, is sufficiently different from other assets to justify exemption from the Act. While an award of damages may be difficult to collect and an unreliable asset, the proceeds of an insurance policy ought not to be so viewed.

The final two exemptions have in common the fact that the property would appear to be unearned, in that it is acquired by a gift from a third party (7(2)(a)) or by inheritance (7(2)(a)). While the term "gift" is reasonably clear, the term "inheritance" may cause some difficulties. It would seem to imply a benefit conferred by a testamentary instrument or by statute by way of intestacy. Presumably, this would include the income from a trust fund set up by a will, but there may be some question as to whether the benefits of an inter vivos trust, even though payable on the death of the settlor, could be termed an inheritance. Similar difficulties would apply to the naming of the beneficiary of the proceeds of an insurance policy, which is by its nature an assignment: ${ }^{89}$ and even more difficult would be the classification of the jus accrescendi in jointly owned property.

There is a rider to the subsection, and it is not strictly accurate to say that any property falling within the exceptions is totally exempt. In fact, it is the market value of the property in paragraphs (a) to (e), either at the date of acquisition or the date of marriage, whichever is the later, which is exempt.

87. Yet another example of the lack of clarity in the Act is the fact that provisions, while juxtaposed, do not complement each other. Section 1(e) deals with a marriage which is void or voidable, while section 2 , immediately following, mentions only a void marriage.

88. Quaere the result where the plaintiff has an alternative cause of action in contract and tort, and chooses the former.

89. Some nice questions have arisen as to whether a document is testamentary in nature. See, for example, Edwards v. Bradley [1956] 2 D.L.R. (2d) 382 and Re MacInnes [1935] S.C.R. 200. 
The difference between the value at that date and its present value is dealt with by subsection 3 , which allows the court to calculate the difference in value between the original property ${ }^{00}$ and the present value of the property substituted for it. ${ }^{91}$ The assumption must be that all such property would appreciate in value, since that statute would hardly direct the court to distribute a $\operatorname{loss}^{92}$.

\section{FACTORS RELEVANT TO THE COURT'S DISCRETION}

The categories created by section 7 are important in that they control the limits of the court's discretion. One must realize, therefore, that the direction to the court as to these categories is as follows: -

i) Exempt Property - the court has no discretion with respect to the market value, at the date of the marriage or acquisition, whichever is later, of exempt property. If the property falls within the categories enumerated in paragraphs (a) to (e) the court must exempt the market value from any distribution.

ii) Distributable Property - the court's discretion is limited only by the requirement of section 7(3) that it distribute property in a manner which appears just and equitable. The court is not hampered by any presumption of equal ownership, but is required to give consideration to the factors enumerated in section 8.

iii) Divisible Property - such property, in terms of section 7(4), must be distributed equally between the spouses unless it appears to the court, having regard to the factors enumerated in section 8 , that it would not be just and equitable to do so.

The nature of the presumption created by section 7(4), requires some scrutiny. No reference is made to a presumption, but the wording of the subsection, that "the court shall distribute equally ... unless it appears ...", leads to the conclusion that the requirement to distribute equally is, in fact, a rebuttable presumption. The result, therefore, is that a party wishing to persuade the court to adopt anything other than an equal distribution must satisfy an onus of proof and overcome an evidentiary burden placed on the party by section 7(4). Furthermore, the onus must be overcome by reference to the factors in section $8 .^{93}$ There would seem to be no doubt that the evidentiary burden is one created between the parties, although the wording of section 7(4) might suggest that the court may, of its own initiative, enquire into the factors which might render an equal distribution not just and equitable.

Perhaps the most significant matter to be determined in the trend of early cases is the ease or difficulty with which the presumption may be displaced and, additionally, how ready and willing the Bench is to descend into the dust of the arena of section 8 factors.

90. As defined in section 7(3)(a)

91. Sections $7(3)(a)(i)$ and (ii)

92. Yet another example of a specific situation being imprecisely translated into a general rule. The result in the case of land given by a parent to one spouse might well be appropriate, but the same result may be inappropriate in the case of another asset.

93. It is probable that paragraph (m) is going to be widely used. 
The factors themselves seem to follow no logical pattern. Indeed, the list seems nothing more than a rag-bag of factors which have been considered in previous cases or urged upon the legislature by various pressure groups. The factors are not water-tight compartments, and will overlap in places. Their relevance is saved only by the open ended nature of the last subsection.

In the first Bill, the list of factors numbered sixteen in all, whereas in the final Act, the number was whittled down to thirteen. The change, however, is not a simple reduction in or combination of the factors, since some of the original factors have no counterpart in the present Act, and vice versa. ${ }^{94}$ Thus, for example, the present section 8 makes no reference to the age, health or conduct of the parties. It is not surprising that this last factor does not appear by name in the final Act. A number of cases dealing with maintenance have clearly established that fault or bad conduct on the part of a spouse will not deprive that person of the right to maintenance under the Divorce Act. ${ }^{95}$ It is clear that the inclusion of conduct as a factor to be considered might lead to the possibility that a right to distribution under the Act would be given as a reward to the faithful and kind, and withheld as a penalty to the unfaithful and unkind. However, it should be noted that a right to maintenance and a right to a distribution of matrimonial property are quite different rights altogether. While it may be logical that the need for support be determined without regard to conduct, it by no means follows that conduct should be irrelevant to the determination of what constitutes a just and equitable distribution of property. This may well be argued where one party alleges that he or she was hampered in the acquisition of property or earning capacity by the conduct of the other party. In summary, a distinction should be drawn between conduct affecting the property and therefore how it should be distributed, and conduct leading to marriage breakdown but not affecting property. While the assumption is often made that conduct must necessarily mean fault, it should not be assumed that the term "conduct" should always carry that connotation. Nor should it be assumed that conduct will not find its way into the consideration of the court even if only as a fact or circumstance that is relevant. The court's dilemma is to determine the degree to which parties will be able to argue that conduct is, in fact, a negative contribution under factors (a), (b) and (c). One danger is that evidence of this nature may reduce the contest to a battle between the parties centering around the animosity of each party towards the other.

Not only has the list of factors been altered, but so too has some of the language used to describe the factors common to both lists. Further, one must question the wisdom of many of the changes, in that they go beyond editing or drafting, and effect substantive changes. For example, the original section 5(ii) which dealt with "income earning capacity, property or other financial resources

(a) which each spouse had at the time of the marriage, and

(b) which each spouse has or is likely to have in the foreseeable future,"

94. To be strictly accurate, paragraphs (iv) to (vii) and (xv) do not appear in the present Act, while paragraphs (b) and (m) of section 8 , did not appear in the original bill.

95. The Common Law rule to that effect has been altered by decisions such as Horne v. Horne (1972) 3 W.W.R. 153. 
and the original section 5(iii), dealing with "the financial needs, obligations and responsibilities which each party has or is likely to have in the foreseeable future", can be contrasted with the present section 8(d) which reads: "The income, earning capacity, liabilities, obligations and other financial resources

i) that each spouse had at the time of marriage, and

ii) that each spouse has at the time of the trial."

The combination of the two clauses of the original Bill leaves one to wonder whether the court is not precluded from projecting into the future the financial status of the parties at the time of trial. Surely the court is to be permitted to conjecture, for example, that the earning capacity of a spouse who has partially completed professional qualifications will not remain static, and that it will change substantially upon completion of the qualifications. Are we to assume further, that the phrase "contribution as a homemaker or parent" is more clear than "contribution made by looking after the home or caring for the family". Perhaps we ought to conclude that the factors are deliberately vague and uninformative.

It would be unfair and imprudent merely to throw up one's hands in despair, without any attempt to examine the factors individually. The following, therefore, is an estimate, or an educated guess as to the intended and possible application of the various factors.

\section{A. The Housewife's Clause}

The purpose of this clause is clearly to introduce into the area of matrimonial property the concept that the work of the party who contributes the traditionally unpaid services of the housewife, should not go unrecognized. (Perhaps the word homemaker was chosen because it smacks less of chauvinism than "housewife", especially in such an emotive context). One should not be deluded into thinking that this is an entirely novel concept. ${ }^{96}$ By contrast, the concept has been around in the area of damages for some time, and the effect of the paragraph is merely to extend a known concept to a new area. It is trite, surely, to suggest that the contributions of the "chief cook and bottle washer" are not, in the context of the family as a whole, of particular significance. Hopefully this paragraph will lay to rest any notions that any contribution or service which does not directly earn money or acquire property is to be ignored.

\section{B. The "Murdoch Clause"}

If one were to summarize the factors that were argued on behalf of the plaintiff in Murdoch v. Murdoch ${ }^{97}$ and subsequent cases, ${ }^{88}$ they could be included in this clause. It would appear that the factor urged upon the courts as a basis for the application of resulting or constructive trusts is that the applicant spouse has in some way made a contribution which has enabled the property to be acquired, improved or developed. Until the decision in Rathwell, ${ }^{, 9}$ the courts had been reluctant to abandon the so-called "safe" ground of looking for an express or implied agreement to share, based on the

96. See for example: Roach v. Yates (1938) 1 K.B. 256; Wattson v.P.L.A. (1969) 1 Lloyd's Rep. 95

97. (1974) 13 R.F.L. 185

98. Fiedler v. Fiedler, supra n. 1; Kowalchuk v. Kowalchuk [1975] 2 W.W.R. 735; Rathwell v. Rathwell, supra n. 1

99. Supra, n. 97 
joint contribution to purchase or the inclusion of the property in a "family enterprise". This factor would appear to be an open invitation to leave that "safe ground" by weighing both financial and non-financial, and direct and indirect contributions.

This paragraph appears to be aimed at a particular situation where a spouse, without pay or promise of reward, has pitched in to enable the business to prosper. It may be important to determine whether there is any difference in the weight to be attached to a contribution under this paragraph and under the previous paragraph. The contribution in issue here is one made to the property aspects of a business or undertaking. Is it to be assumed that the contribution of the spouse who stays home to tend the house (while the other spouse contributes by attending to the business) can be considered only with respect to paragraph (a), or that the same contribution might be regarded as an indirect contribution, in a form other than financial, to the business? It is arguable that the paragraph is aimed at contributions made by a spouse outside the home, but in a business enterprise in which one or both spouses is interested. In a sense, a distinction may be drawn between a contribution to the marital relationship and to the family unit, on the one hand, and to a business enterprise where the parties may be dealing more at arm's length, on the other hand.

One is left to wonder, however, whether paragraph (b) adds anything at all to the preceding factor, other than to give a specific example of the general rule already stated. If the intention was to consider only contributions to business, there may be some question of whether the words "business, farm, enterprise and undertaking" adequately canvass all the appropriate situations. Indeed it would be unfortunate if the specific wording of the paragraph were to cause problems of interpretation which might restrict the meaning of "business, farm, enterprise or undertaking".

\section{Resulting Trust Extended, or Variation Number Three}

If there is some difficulty in explaining the purpose of paragraph (b) then the same difficulty arises a fortiori with respect to paragraph (c). Perhaps the major criticism of earlier decisions relating to matrimonial property was the court's reluctance to extend the equitable doctrine of resulting trust beyond the clear cases where the parties had agreed as to their respective rights to property, or where one party had made a contribution which justified a declaration of trust. It may well be that the courts were entirely justified in refusing to extend judge-made law into an area properly dealt with by statute. By this paragraph, the courts are now firmly propelled into that area. A number of changes, therefore, are brought about in the ground rule that an interest in property will depend upon a contribution by the spouse to the proceeds used to purchase the asset. First, the contribution need not be financial, that is by money or "money's worth" in the traditional sense. Presumably the phrase, "or in some other form" may well include matters falling within paragraph (a). Second, the contribution need not be to the purchase of the asset alone but in addition, to conservation or improvement of it. There is no point in time indicated, therefore, at which the court must conclude that the party either acquired an interest or did not. Finally, the contribution need not necessarily be made by a spouse, personally. The requirement is merely that the contribution be made "by or on behalf of" the spouse. It may be that a benefit conferred upon one spouse by his or her in-laws or other relatives could be deemed to be a contribution "on behalf of" that spouse. 


\section{Balancing Non-Transferable Assets}

While the first three paragraphs appear to assume that a certain amount of property is available for distribution between the parties, and are worded on that basis, paragraph (d) seems to view the distribution of matrimonial property from quite a different viewpoint. Had the paragraph remained in the form in which it was stated in the original Bill, it would have been one of the few clauses to have permitted the courts to look prospectively at the situation and to predict the value of the property in the future. That is not to say that the paragraph as now worded ignores that increase in value of property between the time of marriage and marriage breakdown. Indeed, it is one of the few paragraphs in section 8 which draws attention to the existence of liabilities and obligations which, in a negative sense, may have a direct bearing on the amount and type of matrimonial property available for distribution. Perhaps, of all the section 8 factors, clause (d) most clearly reflects a factual situation which might justify a departure from an equal division under section 7(4). The fact that one party has assumed a large mortgage to purchase a home, for example, or has paid off a large indebtedness, may well justify an unequal division. It could be said that the court is directed by this clause to consider the "net matrimonial property" and the negative aspects of the development of such property.

A further, and the most significant effect of this paragraph, is that it may enable the courts to consider a division in a situation where certain assets may not be transferable at all. The paradigm case is the young professional, newly qualified, and supported while gaining these qualifications by a spouse who has no similar qualifications. The only major asset of the couple is the professional spouse's earning capacity, which, by its nature, is nontransferable. In such a situation this factor could well be used to justify the awarding of all the property, such as it is, to the other spouse. A more fundamental question is whether the court would be prepared, in effect, to require such a spouse to mortgage his or her earning capacity in order to compensate the other spouse.

\section{E. Length of Marriage}

It seems strange that the duration of the marriage in question would have any relevance to the question of whether or not an equal distribution would be just and equitable. Since the property system does not apply to property brought into the marriage at its inception, but merely to property acquired during the marriage it might be argued that this factor must have been intended only to affect the amount or extent of matrimonial property acquired during the marriage, and should not be a factor to be considered in declining to make an equal distribution. Some of the opponents of the deferred sharing scheme, and its mandatory equal division (and it must be assumed that they would be equally opposed to the presumption created by section 7(4) were appalled by the spectre of a flighty young thing who married a wealthy bachelor for his money, and after a short time was happy to leave him minus half of his wealth. That fear is entirely misplaced since the present distribution scheme under the Act exempts property acquired prior to the marriage from distribution in section 7(1). So too is the consideration of this factor misplaced, given the definition of matrimonial property. The danger of including such a factor is the possibility of a nation developing that the right to an equal division must be earned, a question which will turn on the length and harmony of the marriage. It is to be hoped that this factor will not 
assume a great deal of importance. Perhaps the only situation in which this factor might play a role is that where the parties have cohabited for some considerable period of time before finally marrying. ${ }^{100}$

\section{F. The Unharmonious Relationship}

Of all the factors listed in section 8 , this the one most consistent with a factor or consideration which might justify a departure from the presumption of equal sharing. It should not be foregotten that the duty of the court is to apply an equal division as the norm, and to depart from the norm only where the factors suggest it would be just and equitable to do so. One would expect, therefore, that the factors would delineate circumstances which are a departure from the normal marital relationship. Hence the illogicality of the first three paragraphs, which, far from describing a departure from the norm, appear to describe the circumtances in which the norm is to operate. One is tempted to question whether such contributions will be classified by the court as minimal, normal or tremendous. In contrast, factor (f) seems to be entirely consistent with the type of consideration which might justify a departure from the norm. Under this heading, it could be argued that the contribution of one spouse was entirely absent or minimal at best, and that property acquired during such a period should not be subject to a presumption of equality. This factor could also be used to highlight negative aspects of other factors. Thus, it might be argued that once a spouse loosed the millstone from around his or her neck, he or she was able to realize his or her full potential and acquire property accordingly. On the other hand, it must not be assumed that contributions necessarily cease when the parties cease to cohabit or that the effects of prior contributions are immediately cut off. For that reason it is logical that non-cohabitation be a factor to be considered, rather than being exempted from the operation of the Act.

\section{G. Attempted Contracting Out, or "Close But Not Close Enough"}

It is clearly provided, in section $37,{ }^{101}$ that spouses may contract out of the statutory distribution scheme by entering into a written agreement which is enforceable under section 38. It is further provided that Part I, in which section 8 occurs, does not apply to spouses who have entered into such an arrangement. It can only be concluded that if the written agreement falls within sections 37 and 38 , then the court cannot have resort to it as a factor under section 8(g) at least with respect to the property dealt with in the agreement. However, the wording of section 37(1) appears to contemplate an agreement as to a comprehensive property regime, including future property. There is, then, a significant question as to whether Part I can apply to spouses who have entered into such an arrangement, enforceable under section 38, but one which does not cover all of the matrimonial property of the parties. What rationale, therefore, is there for the existence of this factor? If the Act specifies that there is a particular form by which the parties may contract out of the system, the result should be that they will be successful if the

100. For such a situation in divorce, see Feldman v. Feldman (1971)2 R.F.L. 173. It may well be that property acquired during cohabitation prior to marriage would be subject to an argument of a resulting or constructive trust, rather than the list of factors in section 8 which would apply to property acquired after the marriage.

101. For further discussion, see supra, p. 419 
formal requirements are satisfied, and unsuccessful if that is not the case. Why, then, is there the possibility of attempted contracting out entering the affray by the back door? It is, of course, possible that the agreement may not cover all of the matrimonial property and the terms of the agreement may therefore be relevant to the distribution of the remaining property, or, though it purports to deal with all the matrimonial property, the requirements for enforceability in section 38 have not been met. Another possible argument is that such agreements may give the court some clue as to how the parties themselves viewed their respective rights to the property. It is doubtful, however, whether the parties would agree as to the intent of an unenforceable oral agreement, even if it could be satisfactorily proved. A partial agreement might be of considerable aid to the court, if some of the matrimonial property had been transferred pursuant to it. That situation, however, would more appropriately be considered under paragraph (i). It is suggested that this factor might best be utilized by the court to allow review of agreements reached between the spouses where such agreements have been entered into without the presence of the safeguards provided for in section 38. Further, the existence of the agreement may be relevant so as to justify a departure from the norm where the parties have relied on the agreement and where it would unduly prejudice either or both of the spouses if the agreement were upset by the court. Finally, the agreement, whether it falls within section 38 or not, will, if it does not deal with all matrimonial property, be of particular relevance to the distribution of the remaining property. Spouses should be aware, however, that an agreement which does not comply with section 37 and 38 , will not exempt them or their property from the operation of the Act, and it would be unwise to view such an agreement as anything more than one of a number of factors to be considered by the court.

\section{H. The Fraud Factor}

As is to be expected, spouses whose marriage has broken down, and who are contesting their respective rights to matrimonial property may not always act in the most fair and open manner. As a result, the court is necessarily empowered to deal with situations where the defendant has denuded himself or herself of property and thus claims to be more or less order-proof under the Act. The terms of this paragraph should be contrasted with those of section 5(1)(d) where the court is capable of taking jurisdiction to prevent a gift or non-arm's length transaction made by a spouse with the intention of defeating the other spouse's claim under the Act. Attention has already been drawn ${ }^{102}$ to the heavy evidentiary burden placed on the applicant by such a requirement, and of the difficulties arising out of the limitation period prescribed by section 6(3). However, all is not lost, and it would appear that the applicant may raise the nature of a non-arm's length transaction as a factor under section 8 , without the concomitant requirement that the transaction by carried out with the intention of defeating a claim under the Act. Further, it would appear that this factor may be raised whenever an action is properly brought under Part 1 , even though more than two years has elapsed from the time of marriage breakdown, or one year has elapsed since the date of transfer. It is difficult, therefore, to reconcile the provisions of section 5 and 6 with the presence of this fraud factor in section 8 . If the nor- 
mal rule of statutory interpretation were to be followed, the specific wording of sections 5 and 6 would overrule the more general wording of section 8 . However, if a more important rule of interpretation is that the courts should interpret the statute so as to minimize internal inconsistencies, it is suggested that there may be a method of doing so. Both sections 5 and 6 appear to contemplate the court taking jurisdiction to prevent a transfer of specific property or to undo a transfer which took place within the appropriate time frame. If no action is brought within the prescribed period, it would appear that the court cannot order the recapture of that specific property so transferred. The importance of this factor lies in the fact that the court may nevertheless distribute the remaining matrimonial property which is available at the date of the order, having regard to the fact of the non-arm's length or non-market value transaction. Furthermore, the applicant spouse is not encumbered by the evidentiary burden of proving the fraudulent intent of the transferor spouse, but need merely prove the fact of a gift or transfer to a party other than a bona fide purchaser for value. The fact of such a transaction, which the court is otherwise powerless to undo, may well justify a departure from the presumption of an equal division of the remaining matrimonial property on the basis of justice and equity.

\section{Previous Transfers}

The key to this paragraph is the fact that a previous distribution has taken place, whether voluntarily by the spouse, or pursuant to an agreement or court order. Once again the court is placed in a position where it may order an unequal distribution of property having regard to the fact that some property has already been distributed. However, the wording of the paragraph is quite specific,and it may be important to determine whether or not the method of transfer in a particular case falls within those methods of transfer described by the paragraph. While at first glance the wording of paragraph (i) would appear to overlap that of paragraphs (g), (h) and (j), there are a number of subtle but significant differences. First, the term "gift" is restricted to a gift between the spouses and not a gift to a third party, as in paragraph (h). The effect of this provision upon the court's discretion may be twofold, namely, either to regard a previous gift as part of the scheme of distribution made under the Act, or, perhaps, to ignore entirely the fact of the previous gift in making a distribution because the donor has shown an intention to divest himself or herself of the property. In the former case, the property may be deemed to be part of the division awarded to the donor, whereas, in the latter case, the property may be deemed to be part of the matrimonial property, but a part to which the donor makes no claim. Thus, in the latter case, the result may be that the pool of matrimonial property is increased while the rights of the donor are decreased. Second, the paragraph appears to require that an agreement actually be carried into effect. In contrast with paragraph (g), where the terms of an agreement are in question, the consideration of the court under paragraph (i) is directed to the actual distribution pursuant to the agreement. Finally, a distribution of property pursuant to a court order is limited in this paragraph to a "matrimonial property order". It must be assumed that this latter phrase is used in its technical meaning, as given in the definition section of the Act, even though the paragraph makes no mention of this definition, nor does it refer to the powers of the court under sections 7 and 9 . If this assumption is correct, any court order other than a "matrimonial property order" would be relevant only in instances where the court has exercised its jurisdiction under section 5 
to deal with specific property which might otherwise be fraudulently transferred. It is to be hoped that any attempt by a spouse to use this provision to circumvent an earlier decision unfavourable to that spouse, would be given particularly short shrift by the court.

\section{J. Prior Orders}

No specific restrictions are placed by the wording of this paragraph upon the origin of a particular Court Order. It would appear that the court is entitled to consider an Order made by any court, at any level, and, feasibly, from any jurisdiction. Obviously, the level of the court might influence the weight to be accorded to the Order, and the jurisdiction from which it came might also be vital. It is suggested this paragraph should be read in conjunction with section 9(1) dealing with non-Alberta property. An existing order from a foreign jurisdiction in which property is situated will guide the Alberta court as to whether it should exercise the power given to it by section 9(1), namely, that of distributing property within Alberta so as to force an equal or unequal division of total assets. This will be the case particularly where the assets in question are, in a conflicts sense, immoveable property outside Alberta in which case the law of Alberta, not being the lex situs, would not in a normal property context be applicable. ${ }^{103}$ It may also have been intended that this paragraph embrace the terms of the order granted by a court in previous proceedings between the parties, either before the coming into force of the Act, or where, in a Petition for Divorce or application for judicial separation, no attempt was made to join an action under the Matrimonial Property Act.

\section{K. Tax Consequences of Transfer of Property}

It is to be expected that the court should take into consideration the tax consequences of any transfer it may order. Indeed, the Act was not proclaimed in force until it became clear that a transfer ordered by the court within the appropriate time limits could be regarded as an interspousal transfer. ${ }^{104}$ It is trite, therefore, to recite that the court will consider not only the value of the asset transferred, but also the effect of that transfer on both the transferor and transferee. Such effects, for example, as in the case where the transfer of an asset would amount to an actual or deemed realization of an asset, ${ }^{105}$ may well dictate to the court what the contents of an Order should be. On the other hand, the court can hardly be expected to offer a free taxconsulting service to litigants in this area.

Two areas in particular are likely to be of concern to the parties to an application under the Act and persons practising in the area of matrimonial property. First, it must be understood that the legislation has no application to the area of maintenance and support. The function of the court is to distribute the property of the spouses. Whether or not the court orders that

103. The general rule is stated in British South Africa Co. v. Companhia Mocambique [1893] A.C. 602 . The possible characterization of a matrimonial property order will be of some interest. Hitherto, such a propety regime has been regarded as a matrimonial contract, the terms of which should be governed by the proper law of the contract, other than by the lex situs. See DeNicols v. Curlier (1900) A.C. 21; Beaudoin v. Trudel (1937) 1 D.L.R. 216

104. See the provisions of the new subsections under the Income Tax Act, R.S.A. 1952,c. 148, ss. $73(1.1)$ and (1.2), as am.

105. Id., 8. 40. 
the distribution take place by way of periodic payments, the property so transferred is neither income to be included by the recipient nor a deduction for the payor. Second, the possible incidence of a capital gain, consequent on a transfer or disposition, must be borne in mind. While the amendments to section 73 of the Income Tax Act are attempts to alleviate the consequences of a disposition ordered by the court, it cannot be assumed that such transfers can always be treated as internal with no further consequences. These amendments treat the distribution by the court as a "transfer" thus allowing the transferee to receive the property at the adjusted cost base of the transferor. However, if, as is likely to be the case, the major asset is the matrimonial home, consideration should be given to the exemption from taxable gain available to the taxpayer's "principal residence". It is possible, by appropiately combining the provisions of section 40 and 73 of the Income Tax Act, to allow husband and wife to designate separate properties as their "principal residences" while, at the same time, preserving for each of them an exemption from capital gains upon the dispositon of each property. ${ }^{106}$

\section{The Prodigal Spouse}

In a vein similar to that of previous paragraphs, the court in paragraph (1) is entitled to take into consideration what matrimonial property might have been available for distribution but for the wasting of it by one spouse. If one spouse has prevented the acquisition of property by the other spouse, that factor becomes relevant. So too, it is relevant that one spouse has squandered property which would otherwise have been available for distribution. In effect, paragraph (1) treats dissipated property as if it had already been distributed to the spouse who dissipated it, and the extent of that dissipation may justify a departure from the norm of equal sharing. However, the potential of this paragraph seems infinitely broader than some of the others. While the term "dissipate" is not unknown as a legislative term ${ }^{107}$ it would not appear to have any precise meaning. Having regard to paragraph $(\mathrm{h})$, "dissipate" should not be directed primarily at gifts or transfers to parties other than bona fide purchasers for value. If it is directed at the reckless squandering of property by a spouse, it would be reasonable for the curt to consider its effects. However, there remains a question of how reckless, careless or negligent a spouse must be, in order to have "dissipated" property within the meaning of paragraph (1). It can hardly be suggested that every use of matrimonial property has to be consented to by both spouses, and yet an investment which turns sour is likely to be viewed by one spouse, in retrospect, as a reckless venture against which the other party was forewarned. The court, in interpreting the word "dissipate," will be required to draw a fine line between normal and abnormal risks. The questionable use of property could have been supported by a requirement that an element of fraudulent intent be proved, but instead, the paragraph includes an almost innocuous phrase which reads "to the detriment of the other spouse". It could be argued that any act which depletes the matrimonial property available for distribution is, by definition, to the detriment of the other spouse. However, such an interpretation would render the phrase "to the detriment of the other

106. Miles, Income Tax Implications of the Matrimonial Property Act, LESA Seminar Paper.

107. See, for example: The King v. Murphy (1948) S.C.R. 357 
spouse" superfluous. Any other interpretation raises questions in respect of the type of detriment or the extent of detriment required to come within this factor, and the intention or state of mind of the alleged prodigal spouse. It would appear that the Legislature, by the addition of this phrase, contemplated that as a result of the act of dissipation the spouse must have suffered more than the normal risks attendant on ownership of property, and that the dissipating spouse should have been aware of the potential loss to the other spouse yet nevertheless persisted in the activity.

There is here, as under other factors, the danger that the conduct of the respective spouses might again become relevant. If "detriment" were interpreted in any way other than a depletion of resources, serious or otherwise, it might be possible to introduce evidence of the effect of the activity of one spouse upon the other. It has already been stated ${ }^{108}$ that conduct should be relevant only insofar as it affects the extent of matrimonial property, and the fault of one party in bringing about the marriage breakdown should not be argued under this or any other factor.

\section{Any Other Factor}

While it is to be expected that the court should be given a fairly broad mandate to distribute property under the legislation, the basic tenet of the distribution scheme under the Act is that the norm of equal division be adhered to unless the circumstances of a particular case warrant a departure from it. It is surprising, therefore, that the factors in section 8 , as the basis on which the court is to exercise its discretion, should be left so open ended by the inclusion of paragraph $(\mathrm{m})$. The immediate danger of including such a vague clause is that evidence relating to the conduct of the parties or the relationship between the parties might be introduced under this heading. Moreover, it is possible that other factors such as the appearance and demeanour of the parties while giving evidence at trial might become inordinately significant.

It is the attempt to integrate two compatible systems, judicial discretion and deferred sharing, which requires the inclusion of paragraph $(m)$ and thus produces a very untidy set of factors.

Perhaps the best interpretation to be given to this clause is that it forces the court to depart from a mechanical enumeration of the factors, and to consider the overall fairness and equity of the proposed redistribution.

\section{N. Doctrine of Presumption of Advancement}

The task of the court may be eased by the direction in section 36 stipulating that the court shall not apply the doctrine of presumption of advancement to a transaction between the spouses. In fact, that presumption is prelaced by the terms of section 36(2) which, in effect, direct the court to have regard to the result of the transaction rather than the manner in which the transaction came about. Thus, as between the spouses, the court need not determine whether property was given by one spouse to the other, since the court, utilizing the factors outlined in section 8, may redistribute property between spouses. However, in order to determine whether redistribution is necessary at least in terms of the value of property owned by the respective parties, the court is entitled to regard as prima facie proof of joint tenancy, the fact that 
property was placed in the names of both parties. In other words where property is placed in the names of the spouses jointly, or in the case of money on deposit, in the names of both parties, the legal title and the beneficial interest shall, in the absence of specific evidence to the contrary, be presumed to be the same. ${ }^{100}$

\section{O. Summary of General Issues}

The foregoing is an attempt to identify some of the possible and probable interpretations to be made regarding the thirteen factors to be considered by the court. It should not be forgotten, however, that these factors are merely different, albeit overlapping methods of assessment in the task of determining what constitutes a just and equitable redistribution of property. As the number of decisions increases, so will the understanding of the interplay of the various factors. There are, however, a number of broad issues which must be settled in any comprehensive review under the Act, and these broad issues will determine the effectiveness and significance of the Act. It is worthwhile, therefore, to restate some of the issues which the court must address.

\section{The Nature of the Enactment}

There is an endless list of maxims, guides to interpretation, and other rules of thumb to which resort can be had for assistance in the interpretation of a statute. In the end result, the attitude of the court can either be restrictive or liberal, conservative or constructive. In the sense that the statute was prompted by the necessity to cure the inadequacies of existing judicial decisions, it is to be hoped that it would be given a liberal interpretation so that that result might be achieved. It is clear that the courts should not be restricted by the strictures placed upon the remedies of resulting and constructive trusts in previous cases, and, further, that the factors in section 8 are sufficiently broad to encompass much more than contributions to purchase, or express or implied agreements about ownership.

\section{The Norm of Equal Sharing}

Despite statements of the Attorney General ${ }^{110}$ to the effect that the new legislation created equality between the sposues in terms of property ownership, the presumption is created in a surprisingly indirect way. The strength of the presumption is a major issue to be settled by the initial decisions. In turn, that issue will depend on the readiness of courts to resort to the factors in section 8 as a justification for departing from the norm. In particular, what will be regarded as economic misconduct? How much weight will be attached to the fact of living separate and apart? Will the courts depart from the norm more readily in marriages of short duration than in those of long duration? The answers to such questions will determine to a large degree, the extent of changes brought about in present practice by this Act.

\section{The Interplay of the Factors}

With one exception, little has been said of the comparative weighting of the various factors. Factor (a) was given a place of prominence in order to

109. See for example, the difficulties encountered by the operation of the rule with respect to the presumption of advancement, as illustrated by Edwards v. Bradley (1956) 2 D.L.R. (2nd) 382 (Ont. C.A.)

110. Alberta Hansard, supra n. 29 
highlight the recognition which was henceforward to be accorded to a hitherto unrecognized contribution. On the other hand, it was stated that the placement of that factor did not mean that it was any more or less important than any other factor. ${ }^{111}$ It must be anticipated, however, that certain factors are likely to be argued more frequently and given greater prominence than others. For example, the existence of a prior order will likely be used in exceptional cases only, if the practice of joining Petitions for Divorce with applications under the Act becomes accepted. On the other hand, certain factors are likely to be argued in every case and sound advice will involve a knowledge of the potential weight of such factors. It may be that a direct contribution to purchase price is more obvious than an indirect contribution to the maintenance of property, but at the present time, obviousness does not necessarily determine the weight to be accorded each factor. However, once a general trend takes shape, it may well be important to argue that the facts fall under one rather than another paragraph.

\section{Misconduct and its Effects}

Mention has been made of the fact that there is ample scope for the introduction of evidence relating to the conduct of the parties, under a number of the factors required to be considered. On the other hand, it has also been suggested that evidence of such conduct should be restricted to conduct which directly affects the extent of the matrimonial property available for distribution. Even if that restriction is accepted and applied, a number of questions remain to be answered. What, for example, will be considered by the court to be economic misconduct? It is possible that decisions might introduce further adjectival qualifications by the introduction of phrases such as "prudent management"112 or "obvious and gross" misconduct. ${ }^{113}$ What interpretation will the courts give to the wording of section 8(1), where it is alleged that "a spouse has dissipated property to the detriment of the other spouse"? Moreover, will the courts be willing to hear arguments in respect of negative contributions under section 8(a), (b) or (c)?

\section{The Onus of Proof}

The wording of section 7(4) requires the court to distribute the matrimonial property equally between the spouses "unless it appears to the court that it would not be just and equitable to do so ...". Such wording fails to place the onus of proof squarely on the shoulders of one party or the other. Had the wording been "unless it is made to appear to the court", it would be clear that the party opposing an equal division must justify such an unequal division. However, the present wording may mean that the applicant is required to counteract the effects of evidence tendered under section 8 factors, or that the party opposing an equal division is required to satisfy the court that such a division is not justified. It may also be possible that the court may, of its own initiative, require evidence relating to section 8 factors and reach a decision based on that view of the evidence. It is to be hoped that there will be adherence to presumption of equal sharing, and that a party opposing such a division will be required to satisfy the court that such a division would not be just and equitable.

111. Id.

112. See: The Married Persons' Property Act, S.S. 1978, c. 36, s. 22(4)

113. This phrase has been adopted in England to downplay the weight to be accorded to misconduct (Wachtel v. Wachtel (1973) 1 All E.R. 829 and Harnett v. Harnett (1973) 2 All E.R. 593). 


\section{POWERS WHICH THE COURT MAY EXERCISE}

It is important to realise that in order to effect a complete division of matrimonial property between the spouses, the court must be equipped to deal with the property wherever and in whatever form it exists. Moreover, the division ordered by the court should be effective rather than remain an empty order. The powers of the court to distribute property, and the ancillary matters to ensure that such a distribution is in fact carried out, are therefore an important part of the statute.

At the outset, it must be emphasized that there are no conditions precedent to the exercise by the court of the powers enumerated in section 9 . Once the property is deemed to be matrimonial property and not exempt under section $7(2)$, the court may proceed to distribute it. It is no longer necessary to show that the applicant spouse has any legal or equitable interest in the property as a condition precedent to the court transfering it, or redistributing the benefit of it by way of a trust remedy. That requirment is clearly laid to rest by section 36(1) and by the closing words of section 9(2)(c), not only shall the court disregard the presumption of advancement, but it may distribute property to a spouse notwithstanding that the spouse in whose favour the order is made had no prior legal or equitable interest in the property.

It is further intended by the Act that the court effect a global distribution of the matrimonial property and the property situated in Alberta should be distributed with that factor in mind. It is well accepted that any question of ownership of and title to property is governed by the lex situs of the property at the time of the purported transfer. ${ }^{114}$ It would be unfortunate, therefore, if the effect of the matrimonial property order were to depend on the recognition accorded by a foreign jurisdiction, ${ }^{115} \mathrm{a}$ factor which is by no means certain. As a result, the court is empowered by section 9(1) to distribute property within Alberta in such a way as to give effect to a global distribution. In effect, the court may award an unequal distribution of property within Alberta so as to obviate the necessity for proceedings to be brought in a foreign jurisdiction for the purposes of recognizing and enforcing the Alberta court order.

Perhaps the most significant question to be raised with respect to the power of the court, is the determination of whether or not an order to transfer property may be addressed to a third party. With the exception of the limited powers of recapture included in section 10, it would appear that the court is precluded from or at least not empowered by the Act to order a third party to transfer property. The provisions of section 9(2) appear to be limited to cases of transferring property or its equivalent value in money between the spouses, ordering the sale and division of proceeds, or declaring an interest in favour of a spouse. The inclusion of this latter power would strengthen the opinion that the court is limited to a redistribution of property owned by the spouses, between the spouses themselves, and that any act requiring the consent or the co-operation of a third party, is beyond the power of the court to order. If such co-operation becomes a significant factor,

114. See, for example, Goetschius v. Brightman (1927) 245 N.Y. 186

115. For such purpose, other Canadian provinces must be regarded as foreign jurisdictions. In the absence of reciprocal recognition provisions, recognition is by no means guaranteed. 
the applicant would be prudent to attempt to join the third party as a necessary party to the action, in an attempt to have the eventual order enforced against the third party so joined. An additional available manoeuvre to the applicant in limited circumstances and only where a corporation is involved, is to join the corporation as a co-defendant and to argue that the corporation is nothing more than the alter ego of the defendant spouse, with the result that the court should pierce the corporate veil completely or at least deal with the actual assets of the corporation rather than the shares representing those assets. Should the court be unwilling to take such a step, section 9(2)(c) may well be used to create the interest, on the basis of which further negotiation and settlement might take place. There is some question as to the willingness of the courts to take such steps in the absence of a clear and unequivocal mandate to do so. ${ }^{116}$

The general concept of matrimonial property was categorized earlier for the purpose of determining what part or parts was available for distribution under the Act. It may also be useful to divide the property into a further set of categories for the purpose of determining which of the powers available to the court is likely to be used with respect to that property. These categories depend upon the nature of the ownership of the property by one or both spouses, and not, as previously, upon the method of acquisition. Thus section 9(2) provides that the court may transfer property, or the proceeds of sale of that property from one spouse to another, or declare that a spouse has an interest in property. These powers are supported by an array of ancillary powers listed in section 9(3), including the possibility of any order which, in the opinion of the court, is necessary. The extent to which the various powers and ancillary options may be used, will depend upon the desire of the court to effect a distribution in kind of the actual property owned by the spouses, and upon the nature of control over the property exercised by one or both spouses. To illustrate these categories the following charts show the options open to the court under the headings of:

i) Property owned and controlled absolutely by one or both spouses; or

ii) Property owned but not absolutely controlled by one or both spouses; or

iii) Equitable interests in property not controlled by one or both spouses where such interests have not been converted to ownership.

116. The Saskatchewan and British Columbia experience would suggest a very real reluctance. See, for example: Lindberg v. Lindberg (1976)30 R.F.L. 180; Deleeuw v. Deleeuw (1977) 82 D.L.R. (3d) 522 
OWNED AND CONTROLLED

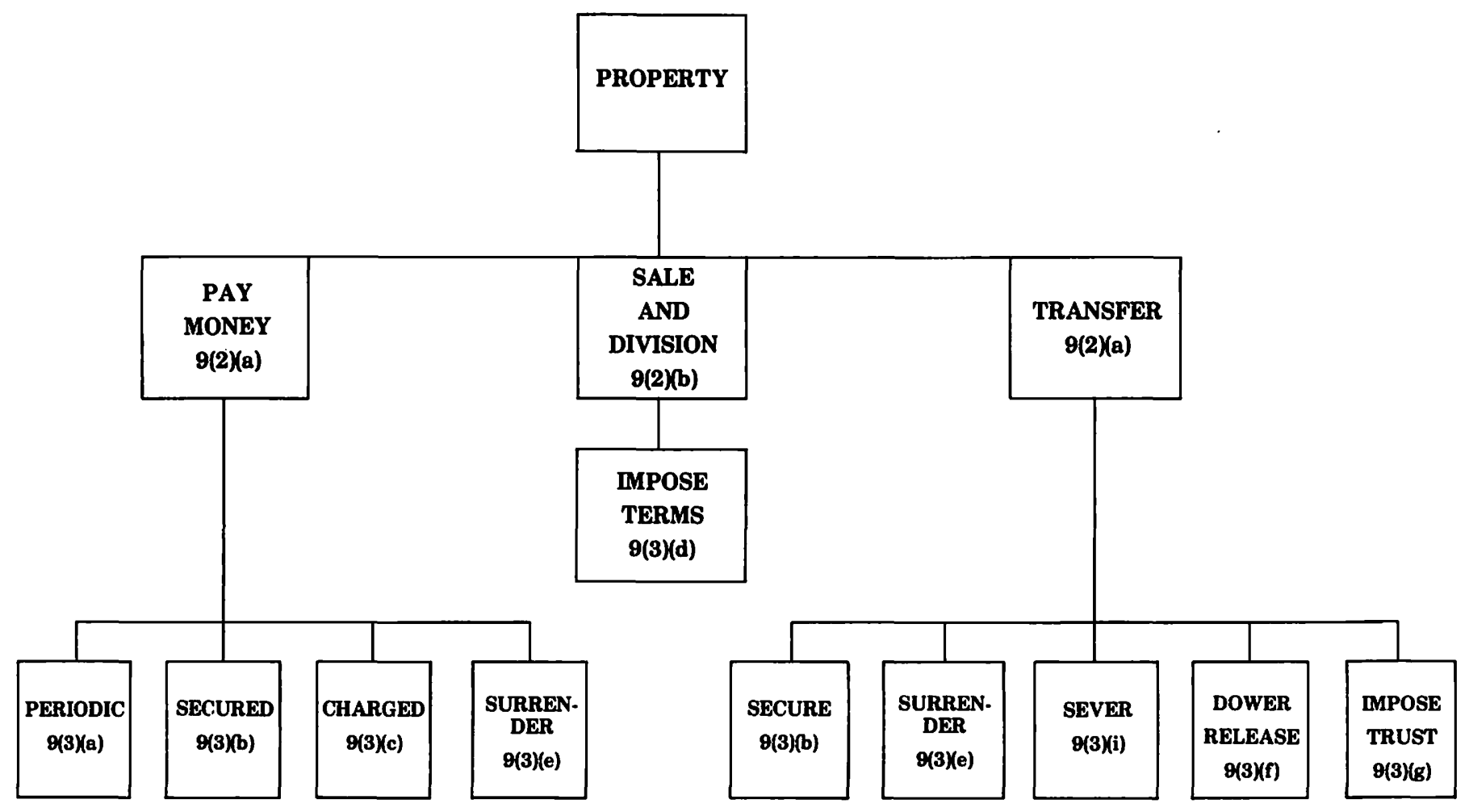


OWNED AND NOT CONTROLLED

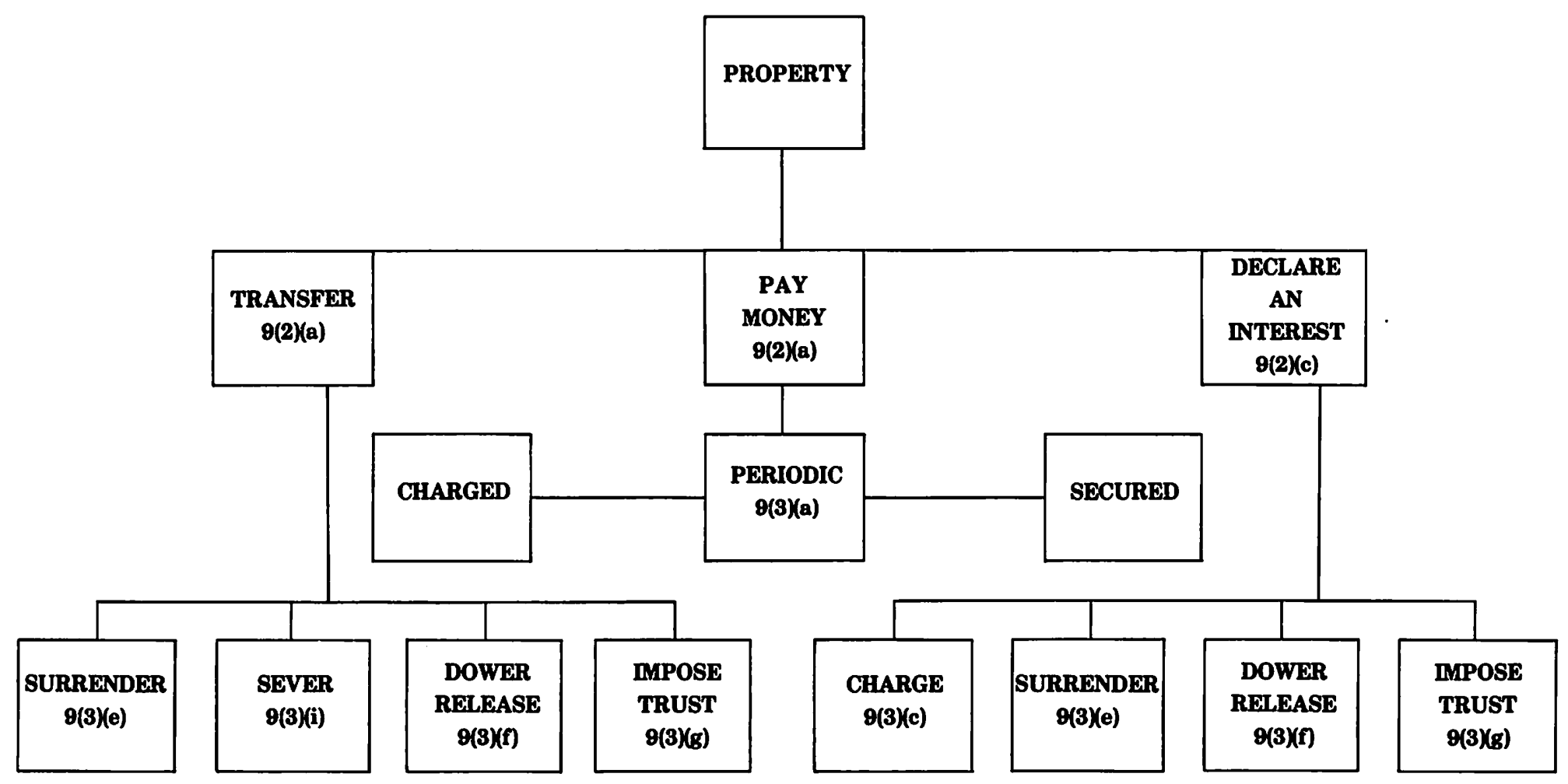


EQUITABLE INTERESTS 
The ancillary powers mentioned in section 9(3) raise a number of specific questions, based largely upon whether the court will follow the same practice as has been adopted in divorce actions. For example, the subsection speaks of the ability to charge an order to pay money against specific property, and in addition provides for an order securing the order to pay. In divorce practice the precise nature of a "securing order" has been difficult to determine, 117 and, in particular, the view has been expressed that an order to secure relieves the payor of any personal liability by requiring the payee to proceed first and solely against the security. ${ }^{118}$ This view appears to be based on the wording of the section of the Divorce Act, ${ }^{110}$ which may be interpreted as providing for a "securing order" as a different species from any other order. However, it is to be hoped that the introductory wording of section 9(3) will make it clear that the security order under the Matrimonial Property Act is an ancillary remedy and does not relieve the payor of his or her personal liability.

On the other hand, it should not be assumed that the practice and jurisprudence under the Divorce Act and the Matrimonial Property Act will be entirely assimilated. The differing purposes of the two statutes must be borne in mind, one providing for a division of property, the other for maintenance and support. Thus, it by no means follows that the same principles will apply to the propriety of a lump sum as opposed to a periodic pay. ment under the two Acts. ${ }^{220}$ It has already been stated, and it bears repeating, that a Matrimonial Property Order will not, even if it is to be paid on a periodic basis, entitle the payor to deduct the payment from his gross income or subject the payment received to tax in the hands of the payee. The purpose of the periodic payment under the Matrimonial Property Act is the convenience of payment, rather than a balancing of income.

The purpose of the charts, therefore, is to indicate the possible powers which the court may exercise in respect of the property included in each category. The first category would include all property solely or jointly owned by the spouses. It is contemplated that any property falling in category (i) could be properly transferred by one spouse to the other as a result of a matrimonial property order, without further ado. Category (ii) is intended to deal with those types of property which, while absolutely owned by one or both spouses, also involve an element of control by a third party, or at least depend upon the co-operation of a third party for effective transfer. The paradigm example of such property is shares in a private company which reguire the approval of the directors before a valid transfer may take place. Similarly a vested right to receive property trom a trust fund might require co-operation from the trustee. In these cases there may be some doubt as to the power of the court to order the directors to approve the transfer, or the trustee to change the terms of the trust. Category (iii) includes those rights and interests which are possessed by one or both spouses, and therefore must be included as part of matrimonial property, but which can hardly be described as ownership in respect of the asset in which the interest is granted. Such interests might include the purchaser's interest under a conditional sale

117. See, for example: Van Zyderveld v. Van Zyderveld (1975) 4 W.W.R. 127

118. Id.

119. Divorce Act, R.S.C. 1970, c. D-8, 8. 11(1)(a)

120. Contrast the judgment of Moir, J. in Krause v. Krause, supra n. 13 
agreement, the right to receive royalties under a licence or assignment, or even an exclusive right to use and enjoy certain property. While it might be technically correct to describe the right as as asset owned by the spouses, it is practically necessary to think in terms of the asset in which the right exists, if the transfer of the right is to be a significant part of redistribution of matrimonial property.

The significance of the categories is dependent, therefore, upon the manner in which the court views its mandate under the statute. It should be noted that each category contains, as a major power, the power to order the payment of money. It is always open to the court to value the assets of the parties and to fix in terms of a dollar amount the sum necessary to effect the appropriate redistribution of property between the spouses. Indeed, the regulations $^{121}$ are couched in terms of a valuation process which will result in a dollar amount. ${ }^{122}$ If the process of valuation and division were adopted by the court, the power to order a money transfer, secured or charged, and in a lump sum or on a periodic basis, would be the only power needed by the court. On the other hand, the powers of the court are sufficiently broad that it must be assumed that the statute also envisages a distribution of property in kind. In some cases, distribution in kind might be preferable to an order to pay money, if the value of the property fluctuates with the market or is dependent upon orderly realization. ${ }^{123}$

It is suggested that the court should not necessarily be content with redistribution of property by way of a balancing payment, and that the court should quite properly be concerned with distribution in kind. If that is the case, then the distribution will depend upon the ability of the spouses to give effect to it, with or without the co-operation of third parties, and upon the nature of the interest to be redistributed. It is at this stage that the powers described in categories (ii) and (iii) become significant, and, in particular, the ability of the court to ensure that the suggested distribution is actually carried into effect will depend upon an adroit use of the ancilliary powers.

Further, it is suggested that it may be prudent to attempt to join as a party to the action any party whose co-operation is necessary for the proper and valid transfer of any particular piece of property. Such a joinder might be justified on the basis that the presence of the third party is necessary in order to enable the court to grant the plaintiff the relief for which he or she asks. ${ }^{124}$ Some caution is urged in the use of such a procedure since any abuse of the right to join a necessary party may well result in the joinder being struck out, with appropriate consequences in costs. ${ }^{125}$

In certain limited circumstances, ${ }^{126}$ the court may be capable of recapturing property which a spouse has purported to transfer to a third party. Certain conditions precedent are necessary before recapture can take place, and they are that:

121. O.C. $1352 / 78$

122. The necessity to have the incremental value of exempt property and to value other parts of matrimonial property may well call for much more accurate record-keeping than is currently the record.

123. See Feldman v. Feldman (1975) 75 W.W.R. 715

124. See: Alberta Rules of Court, R. 38(3); Griese and Wood Ltd. v. Loewen, Harvey and Humble, Ltd. (1914) 6 W.W.R. 698 (Sask.)

125. Alberta Rules of Court, R. 129

126. Section 10 
i) the consideration was less than adequate;

ii) the transferor intended to defeat the Act;

iii) the transferee knew or ought to have known of the mala fides of the transferor;

iv) the transaction took place within one year prior to the application.

If all of the conditions precedent are satisfied, then the court may order that all or part of the property be transferred to a spouse. It is to be presumed that the court will limit its powers of recapture to the difference between the actual consideration paid and the market value at the time of transfer. If the consideration is non existent or derisory, it would seem reasonable that all of the property be transferred, whereas, if the consideration is less than adequate (that is, the third party is not a purchaser for value) the court should be hesitant to penalize the third party by requiring the transfer of all of the property as a sanction upon the third party's duplicity. If the latter were to be the operative view one would have expected the wording of the section to be a great deal more explicit. In the light of the wording of section 10(e) it is likely that the court will rarely exercise its discretion to order the transferee to transfer all of the property where the value of the property is not considerably greater than the consideration provided by the transferee. This is all the more likely since the court may use the provisions of section $10(\mathrm{~g})$ to deem the property transferred to be part of the share of the matrimonial property awarded to the transferor. Unless there is some compelling reason why it is necessary to recapture the specific article or piece of property, for example, property of lesser capital value but likely to produce a significant rate of return in the future, the court is likely to be content with the process of valuation and division available under section 10(e) and (f).

It would appear that the powers of recapture are not limited to inter vivos dispositions, but could be extended to bequests and devises by will or distribution on intestacy. The provisions of section 15 make it abundantly clear that the transferee or payee under a matrimonial property order takes priority over beneficiaries by will or intestacy, ${ }^{127}$ or a dependant-applicant under the Family Relief Act. ${ }^{128}$ Indeed the Act contains a number of provisions designed to ensure that a surviving spouse will be entitled to the adjudication of the court under the Matrimonial Property Act, prior to the distribution of any part of the deceased's estate. Thus, section 12 allows the court to suspend all or part of the administration of an estate pending an application under the Act, and section 13 imposes personal liability upon the personal representative who distributes property without the consent of the living spouse, or without an order of the court, if the property so distributed is eventually included in the matrimonial property order made by the court. Moreover, the personal representative is personally liable, according to section 14(2), if he fails to distribute the property in accordance with the court order. ${ }^{120}$

127. Typical of the loose terminology employed by the Act is the use of the phrase "beneficiary under the Intestate Succession Act". At no point in history have the distributees or heirs on intestacy been described as "beneficiaries".

128. This is in stark contrast to the position of a contractual promisee whose position vis-a-vis dependants - applicants under the Family Relief Act or equivalent legislation, has been the subject of some debate. See, for example, Re Richardson's Estate (1935-35) 29 Tas. L.R. 149 and $R e$ Dillon deceased (1941) A.C. 294

129. The terms of a fairly normal clause in wills, absolving the personal representative from personal liability, will probably not be adequate to remove the liability statutorily imposed by sections $13(2)$ and 14(2). 
The powers of the court in respect of the estate of a deceased person are circumscribed by two sections of the Act. Section 11(2) provides that an application may be made by a surviving spouse only where an application could have been commenced immediately prior to the death of a spouse. That provision raises the question of whether an action could have been commenced prior to the death, which will depend, in turn, upon the provisions of sections 5 and 6 . Thus an application may have been properly commenced prior to the death of a spouse, if the spouses were divorced, judicially separated, living separate and apart for at least one year (or less than one year where there is no possibility of reconciliation), or where the marriage had been annulled, and if the time limits prescribed by section 6 had not expired. In fact, these provisions create the unusual situation where a spouse in a harmonious marital relationship must be content with the provisions or a will or intestacy, supported by Dower and Family Relief legislation and trust remedies, while a spouse whose marriage has broken down may take advantage of the potentially more generous provisions of the Matrimonial Property Act. ${ }^{130}$ While the difficulties of this distinction may be tempered somewhat by the requirement of section 11(3) that the court take into account the benefits received by the applicant as a result of death of the deceased spouse, there remains some lingering doubt as to the inherent propriety of such a distinction. The surviving spouse in a harmonious relationship has no guarantee of an equal interest in his or her spouse's property, nor is the right to apply under the Family Relief Act any guarantee of a share of the deceased spouse's estate. ${ }^{131}$ Thus the surviving spouse in such a relationship would be forced, in any dispute in respect of the status of property, to restrict arguments to the common law principles, the very inadequacies of which are supposedly redressed by the Matrimonial Property Act. ${ }^{132}$

Furthermore, the right to bring an application is described by section 16 as a purely personal right which, notwithstanding the provisions of the Survival of Actions Act, ${ }^{133}$ does not survive the death of a spouse. At first blush, such a provision appears somewhat surprising since, as a general rule, actions in respect of proprietary rights normally survive the death of a party and may be continued by the personal representative of the deceased for the benefit of the estate. Indeed, section 15 appears, from the point of view of the payor under a matrimonial property order, to create retroactively the state of affairs which ought to have existed prior to the death of the spouse. ${ }^{134}$ While there may be no logical reason to deny the survival of the right to apply, there may well be cogent practical reasons not to do so. The court is required to exercise a considerable discretion based on the evidence of the parties themselves, which, of course, would be much more difficult when one of

130. This may be unusual, or even undesirable, but is entirely consistent with the application of the legislation in circumstances of marriage breakdown only. Perhaps the legislation might be extended to apply, in addition, to termination of marriage, including termination by natural causes.

131. The operation of that statute is premised initially on the need for support of the applicant. See the general principles stated in $R e$ Willan, supra n. 15

132. Supra, n. 1

133. S.A. 1978, c. 35

134. Money or property is deemed never to have been part of the estate for certain purposes. It should be noted that the purposes are limited and specifically do not include creditors of the estate. 
them is unable to provide that evidence. Such a reason would not be presented in a "deferred sharing" scheme and the reader of the Act is left to wonder whether much thought was given to the effects of the introduction of discretionary factors.

In order to facilitate the adjudication of the court on the matrimonial property of spouses, certain interim orders may be made. Indeed it is infinitely more sensible to restrain an action which would defeat a claim under the Act than to recapture an asset once disposed of. To that end, the court may wish, in effect, to freeze the assets of the parties pending final determination of the rights of the parties. However, the powers of the court to accomplish that purpose are quite severely limited by the terms of sections 33 and 34 . In fact, the court may act merely to prevent a gift or sale to a party who is not a bona fide purchaser for value. No other general power to maintain the status quo, pending determination of rights, is included in the statute, and any attempt to do so must necessarily be based on the court's inherent powers to ensure a proper and fair adjudication. Indeed, the prohibition in section 33, which bears the euphemistic marginal heading of "disposition prohibited during proceedings", is limited to the disposition or encumbrance of household goods, or the removal of household appliances and furnishings from the matrimonial home. Thus the prohibition is directed at the disposal of property which might be the subject of included household goods in a matrimonial home possession order. Why, then, should the term "household goods" be further limited, for purposes of such a prohibition, by section 33(1))b) which limits the term to household appliances, effects and furnishings.

More useful to the applicant, in terms of general preservation of property, is the provision of section 35 which permits the filing of a Certificate of Lis Pendens. Clearly, the filing of such a Certificate may prevent the disposition of a particular piece of real property, since a potential purchaser is unlikely to risk the purchase of property where a memorandum of the Certificate of Lis Pendens is noted on the Certificate of Title. However, it is curious that the direction to the Registrar to make and record the memorandum is prefaced by the phrase "if the description of the land is known". The provision is therefore open to the interpretation that a Certificate may be filed without the necessity of a description of land, thus presenting a large stumbling block to the other spouse dealing with any real property in the land registration district, whether or not the status of that property is in dispute..$^{135}$

The provisions of section 31 may go a long way to reducing the difficulties of proof of ownership of property by the requirement that each party must provide and serve on the other a sworn statement detailing the property which might be subject to an order under the Act. ${ }^{138}$ That is not to say that there will not be differences of opinion over questions such as valuation, or the exempt status of property, or the method of acquisition of property. On the other hand, a proper completion of the "Statement of Property" called for will require a very thorough search of records and accounts. That alone would be an improvement over the general impressions and loose powers of recollection which may often be encountered in examinations for discovery at the present time.

135. The form of a certificate of lis pendens is set out in the regulations contained in Orders-inCouncil 1352/78, Form B.

136. Id., Form A. 


\section{MATRIMONIAL HOME POSSESSION}

\section{A. Existing Restraining Orders}

It has long been recognized that the preservation of a residence for the surviving spouse and family is a socially desirable and acceptable goal. Indeed, the "homestead legislation" of various Canadian provinces bears this out. ${ }^{137}$ There is no reason why such a policy should not be extended to the termination of marriage by breakdown as well as by death, and it is the function of Part 2 of the Matrimonial Property Act to empower the courts to ensure that such a policy may be achieved. Thus the court is empowered to award exclusive possession of the matrimonial home, or the interest in property occupied by the spouses as their matrimonial home, and further, if necessary, to ensure that such exclusive possession is not disturbed. ${ }^{138}$

That the courts should pursue the policy of preserving the matrimonial home for one spouse upon marriage breakdown is not a novel contention. Indeed, through the granting of what is commonly described as a "Restraining Order" the practice of attempting to award exclusive possession of property has become more or less accepted. While the power to grant such orders was based on the inherent power of the court to maintain the status quo prior to trial and to ensure proper hearing of cases without intimidation or threat of retaliation, it was by no means clear that the court could achieve all it purported to, and even then, the circumstances in which the power should be exercised were open to some debate. ${ }^{139}$

Two problems, in particular, became apparent in the practice prior to the enactment of Part 2. Since Restraining Orders were dealt with as ancillary to a Petition for Divorce, the force of the order was spent once the Petition was heard and a Decree Nisi pronounced. Attempts to incorporate a permanent Restraining Order in a Decree Nisi were problematic to say the least. ${ }^{140}$ The preservation for the family of the matrimonial home was, therefore, an indirect result of prohibiting one spouse from annoying, interfering with or molesting the other spouse in or around the matrimonial home. There was nothing to prevent the restrained spouse from exercising any proprietary rights which he or she might have. If, as was common, the home was registered in the name of the restrained spouse alone, there was nothing the court could do to prevent that spouse from evicting the other spouse and family. To avoid that difficulty, it was the practice of some members of the judiciary to make the award of maintenance conditional upon the recipient spouse being able to remain in the matrimonial home, and, if necessary, to attach the sanction of an increase in maintenance of varying proportions (sometimes astronomic) if that condition were breached. Even that ploy was open to objection where the property was jointly owned, since one spouse could bring an action for partition and sale. Until comparatively recently, it was thought that such an action could not be opposed, and that view held sway until the Alberta Appellate Division reserved to itself an element of discretion in granting or refusing an order for partition and sale. ${ }^{141}$.

137. See, for example: The Dower Act, R.S.A. 1970, c. 114; The Married Women's Property Act, R.S.B.C. 1960, c. 233; The Married Women's Property Act, R.S.S. 1965, c. 340.

138. Sections 19(1)(a), (b) and (c)

139. Mathieson v. Mathieson (1975) 17 R.F.L. 354 (Alta. L.A.)

140. Some attempts have been successful and the decree nisi has ordered a permanent separation of the spouses sanctioned by the power to arrest a disobedient spouse.

141. Clarke v. Clarke (1974) 15 R.F.L. 115 


\section{B. Home Possession Orders}

With the advent of Part 2 of the Matrimonial Property Act, the court has a wide ranging discretion to order interim and permanent possession of the matrimonial home, and the household goods used in association with it. While section 19 parallels the former practice in most respects, it should meet most of the inadequacies of the former practice by allowing the court to achieve directly what it could formerly do only indirectly. It is no longer necessary to link a home possession order to maintenance nor is it necessary, in order to be successful, to make the standard allegation that the applicant is afraid for his or her personal safety. Moreover, it no longer matters which spouse owns the matrimonial home, and a possessory order is not to be defeated by a subsequent action for eviction or partition and sale. The various subsections of section 19 do not provide for an accompanying nonmolestation order in respect of activity away from the matrimonial home, but there is no reason why the court could not invoke its inherent jurisdiction to grant such an order.

The court is given a modicum of guidance by the terms of section 20 in respect of the bases upon which a possessory order should be granted. The four factors which are listed are: the availability of other accommodation within the means of both spouses; the needs of children residing in the home; the financial position of each spouse; and any order of a court with respect to the property or maintenance of the spouses. At first sight, these factors appear to be fairly obvious considerations for any common sense approach. They are nevertheless real considerations with an important part to play. The reader may be tempted to separate Parts 1 and 2 of the Act, especially in view of their original form as two separate bills. However, the possession of the matrimonial home, usually one of the major family assets, is a major factor in the distribution of property. A redistribution of property which results in the sale of the matrimonial home, forcing one spouse and family into less than adequate accommodation, can hardly be described as just and equitable. Perhaps the most common use of Part 2 will be the granting of an interim order which will give the parties some time to effect an orderly distribution of their matrimonial property. However, it should not be thought that possession and ownership of the matrimonial home go hand in hand. Such is not the case, since a possessory order can relate to the interest of a spouse, whether by ownership or lease, or even by way of a life estate. The key question is whether or not it is in the interests of one spouse and within the means of the spouse or spouses to grant exclusive possession of the matrimonial home to one spouse. ${ }^{142}$ Thus, consistent with such a theme, a possessory order may be registered against real property under section 22 , or registered with the Vehicle Registry under section 23, and an order in respect of household goods may be registered either in the Vehicle Registry or in the Chattel Securities Registry, as the case may be. In all senses, a possessory order once registered is to be an effective, exclusive order having priority over all other claims which may arise subsequently. Indeed, in accordance with section 27 , registration constitutes valid notice to subsequent creditors, purchasers and mortgagees.

142. Similar factors are in use in Ontario. See, for example: Cicero v. Cicero, Unified Family Court of Hamilton - Wentworth (Ontario), June 15, 1978. 


\section{Registration of Orders}

The powers of registration of possessory orders will aid significantly in regularizing the status of a spouse in possession of goods owned by the other spouse. Hitherto rights of possession granted by separation agreements or appended to maintenance awards have lacked the status to allow third parties to recognize them. Thus, for example, considerable difficulty might be encountered by a spouse applying for the issue of licence plates for a vehicle owned by and registered in the name of the other spouse. However, the added recognition accorded possessory rights may also carry concomitant obligations such as the necessity to insure for the spouse's insurable interest. There may also be some question whether the interposition of one spouse in a lease entered into by the other spouse would also entail liability for arrears of rent. While section 24 provides that the spouse having possessory rights shall be "deemed to be the tenant for the purposes of the lease", it makes no mention of liability for pre-existing obligations under the lease. The cautious practitioner would be well advised to ensure that there are no such pre-existing obligations, or, at least, that the court absolve the spouse from liability.

\section{Commencement of Actions Under Part 2}

It is contemplated in section 30 that an application for a matrimonial home possession order may be commenced independently or in conjunction with another matrimonial cause. In each case, the normal rules requiring service, notice and examination for discovery would be applicable. There is, however, provision in section 30(2)allowing the court to act on an ex parte application, and without notice, if the circumstances justify such a departure from the rules. The controlling element, as stated in subsection (2), is the presence of "danger to the applicant spouse or a child residing in the matrimonial home as a result of the conduct of the respondent spouse". It is expected that this clause will be interpreted in such a way as to require real or apprehended physical danger to the applicant or children. Mere unpleasantness or incompatibility would hardly be regarded as danger or injury. Perhaps some guidance might be obtained from the cases decided under section $3(\mathrm{~d})$ of the Divorce Act, under which the court is required to decide whether the conduct in question renders continued cohabitation intolerable.

It is to be hoped that the possibility of orders under Part 2 in respect of the matrimonial home will be viewed in the remedial sense in which it was intended. The court is equipped with considerable tools to ensure that the "family" is not unduly uprooted upon marriage breakdown. On the other hand, the scope of these tools may open the door to the possibility of abuse. It is therefore equally to be hoped that any attempt to use the provisions of Part 2 as a simple negotiating tool, or as means of hastening the departure of an unwanted spouse, should be discouraged.

\section{E. Problems of Definition}

Some substantial questions may be raised as to the applicability of Part 2 of the Act. Such questions arise particularly with regard to the definitions of "household goods" and "matrimonial home" contained in sections (1)(b) and (c).

"Household goods" has been defined in the Act as "personal property that is owned by one or both spouses". It is arguable, therefore, that the requirement of ownership effectively removes from consideration property subject to a conditional sales agreement where the purchaser cannot be said to be the 
owner until full payment has in fact been made. This would be the result if the right to become owner is regarded as something less than ownership itself. It is clear that the interest of the conditional purchaser is not ownership vis-a-vis the conditional vendor and there is considerable doubt as to whether that proposition should not apply vis-a-vis third parties or the spouse of a conditional purchaser. ${ }^{148}$ However, further conditions are attached to this definition before such property can be considered to be "household goods" within the meaning of the Act, and therefore included in an order for "exclusive use and enjoyment" in section 25(1). The property must have been "ordinarily used or enjoyed" by one or both spouses, or by one or more of the children "residing in the matrimonial home". Hence, it appears that the use of such property by a child not living in the matrimonial home, would not be subject to an order under section 25 . Further, section 1(b)(ii) delineates the purposes to which such personal property should be put, in order to qualify as "household goods". These are "transportation, household, educational, recreational, social and aesthetic purposes". Such purposes, whether by coincidence or not, are the same purposes as are described in the Ontario Family Law Reform Act, and more specifically under the definition of family assets in section 3(b). Presumably, they will be broad enough to cover all possible categories of personal property. Hence, so long as the goods owned are personal property, and are ordinarily used or enjoyed by one or both of the spouses or their children, they will potentially be available as the subject matter of a section 25 order.

Greater problems are derived from the definition of "matrimonial home". The use of commas, and the conjunctive "and" in section 1(c), render the provisions of subsections (i) and (ii) mandatory. Therefore, if the property cannot be said to have been "owned or leased by one or both spouses", nor can it be said that the property "is or has been occupied by the spouses as their family home", it will not be a "matrimonial home". Again, without some judicial dexterity and even prestiditation, property subject to a conditional sales agreement, such as a mobile home will not be a "matrimonial home on the basis of this definition. Thus, for example, it might be necessary to argue that a mobile home is a fixture appurtenant to real property owned by one or both spouses, thus finessing the argument in respect of ownership. Further questions may be raised as to the meaning of the term "family home," a term which does not appear to have been used in prior jurisprudence. It is to be hoped that this requirement will be viewed leniently by the courts, and premises occupied by the spouses together will be sufficient to qualify, if the other requirements are also met.

A third requirement with respect to matrimonial home, in addition to the requirement that the property be owned or leased by one spouse, and have been occupied as a family home, is that it fall within the categories enumerated in section (iii) paragraphs (A) to (E). While these categories seem to be intended to cover the range of most types of accommodation, the terminology is lacking in certainty. One may question the meaning of a phrase such as "self-contained dwelling unit" which is used to qualify a house or part of a house. One may further question whether or not a "suite" is to be given its technical meaning, as used by municipal authorities for purposes of development permission, or its vernacular meaning.

143. See for example: Workmen's Compensation Board v. U.S. Steel (1956) 18 W.W.R. 403 (Alta. S.C.). 
It is to be hoped that the difficulties of definition of the terms "matrimonial home" and "household goods", will be viewed in the light of the basic purpose of Part 2, of the Act, that is, to enable the court to ensure that a spouse and family are permitted to continue to live in the matrimonial home and to use the household goods which they previously used in association with the matrimonial home. It would be most unfortunate if the definitions were to thwart such a purpose.

\section{CONTRACTING OUT OF THE STATUTORY REGIME}

It is specifically contemplated in section 37 that spouses may not wish to adhere to the property regime established in Part 1 of the act. If the spouses are so minded, they may avoid the statutory scheme by entering into an agreement which falls within the terms of section 37, and satisfies the formal requirements of section 38 . While such provisions may loosely be described as "contracting out" of the statutory scheme, such a description is not literally accurate. It is doubtful that an agreement not to be bound by Part 1 , with nothing more, would constitute an appropriate agreement within the terms of section 37 . It would be more accurate to say that spouses may choose to replace the statutory scheme with one of their own choosing, by entering into an agreement which effectively substitutes the scheme so chosen. Perhaps the terms of sections 37 and 38 should be viewed primarily as allowing spouses to contract into alternative schemes, the effect of contracting out of the statutory scheme being a secondary corollary.

It must be realised that spouses are not at liberty to replace the terms of Part 2 with respect to the matrimonial home and household goods. There is clear authority to the effect that parties may not, by private bargain, contract out of a statute which is enacted for the public benefit. ${ }^{144}$ It would appear that the provisions of Part 2 are so important that they cannot be tampered with in private contracts.

It is in order, therefore, to examine the terms of sections 37 and 38 , to determine the circumstances in which and the methods by which parties may opt out of the statutory scheme and into an alternative scheme.

The exact means of replacing the statutory scheme is stated by section $37(1)$ to be by way of an "agreement in writing". It does not appear that such an agreement need be entered into expressly for the purpose of replacing the statutory scheme, nor that it be entered into at any specific time. However, unless the agreement deals with the "status, ownership and division" of matrimonial property it will not constitute an agreement which excludes the application of Part 1. It would appear, therefore, that the application of Part 1 may, in theory, be displaced by an ante-nuptial, or post-nuptial agreement, by a separation agreement or by minutes of settlement. Indeed, an antenuptial marriage contract is specifically provided for in section 37(2). The result of a reasonable interpretation of section 37 would lead to the conclusion that any agreement which deals, as a minimum, with the matters falling with Part 1, will effectively substitute the agreement for the statutory scheme of Part 1. It will not be fatal to an agreement, for example, that it provides for the distribution of property at any time, even where there is no marriage breakdown in terms of section 5 . 
While it is contemplated that an "agreement" may be found to exist in a more broad contract such as an ante-nuptial marriage contract, it is significant that the term "contract" does not appear in section 37 . The term employed throughout is "agreement", and it is arguable that the use of that word is designed to remove the requirement of consideration. This is borne out by the terms of section 38 , which make no mention of consideration. Of course, consideration may subsist in any event in an agreement in which the parties exchange mutual promises. Moreover, the term "agreement" may well be intended to apply to situations where the parties have not formally recorded their agreement in a contractual document, but where it is possible to gather the intention of the parties from a collection of written documents. In such a situation, the requirement of writing may merely ensure that there is available some reasonable record of the agreement, more acceptable than the oral evidence of the parties.

The opening words of section 37(1) state that the provisions of Part 1 do not apply to spouses who have entered into an agreement. No precise definition is given, however, of the time at which the spouses should have entered into such an agreement. It is clear that the parties may enter into an agreement within the terms of section 37 prior to marriage, and it is also submitted that the spouses may enter into such an agreement prior to the happening of any of the circumstances of marriage breakdown enumerated in section 5 . What is not clear is the question of whether an agreement entered into by the spouses after marriage breakdown, but within the time limits of an application under Part 1, will effectively oust the court's jurisdiction to exercise the discretion given to it by Part 1 . In divorce actions, the court has the power to examine and, if necessary, refuse to approve the terms of minutes of settlement. In certain circumstances the court may even withhold the granting of a decree nisi, due to a disapproval of minutes of settlement. It would be incongruous, therefore, if a factor specifically mentioned in section 8(i) and (j), were also a factor which entirely excluded the court's jurisdiction under Part 1 . In a similar vein, it might be possible that the spouses could commence an action under Part 1, agree to settle the action by an agreement falling within section 37, and thereby remove the terms of the settlement from any review by the court. This would clearly be the case if the terms of section 37(1), namely, "spouses who have entered into a subsisting agreement," are interpreted as making Part 1 inapplicable in any situation where the spouses have entered into such an agreement prior to the granting of an order under Part 1. It is suggested that the court might wish to review the terms of such agreements. and the wording of section 37(1) will place great emphasis upon the early decisions as to the timing of an agreement which is capable of ousting the court's jurisdiction.

Not only is it necessary that the agreement be in writing and that it be executed at the appropriate time, but also that the agreement deal with the appropriate subject matter. Thus, section 37 stipulates that the agreement should deal with the "status, ownership and division of property". It would appear that this phrase is intended to paraphrase the functions of the court under Part 1. Thus, under the heading "status", the parties should determine what property is to be part of the agreement and what, if any, is not. This deliberation would be the equivalent of section 7(2). The term "ownership" should be used so as to determine who has the ultimate control over a particular piece of property, and will be a useful classification prior to, or in place of, a division of property between the parties. This term may also deter- 
mine the effects of the inter-spousal agreement on third parties. The operative segment of any agreement must be the division, or method of division which will take effect on dissolution of the marriage or separation of the parties. ${ }^{145}$ Thus, while there appears to be no limit to the permutations of divisions and schemes to which the parties may agree, it is imperative that the agreement include provisions dealing with the three terms mentioned above. Moreover, the agreement, if it is to render Part 1 inapplicable, should not be limited to property owned at the time of marriage, or to a specific piece of property. The addition of the phrase "including future property" would seem to indicate that the agreement should contain a scheme of division which will apply to all property of the spouses, including any property acquired in the future. In such a case, dealing with specific property, the provisions of Part 1 are nonetheless applicable despite the terms of the agreement, although the court may consider the terms of the agreement under section $8(\mathrm{~g})$. Section 37 , therefore, appears to contemplate a comprehensive scheme adopted by the parties to govern their matrimonial property, and it would appear that limited or specific ad hoc agreements will not displace the applicability of Part 1 of the Act.

It should also be pointed out that the ability to contract out of the provisions of Part 1 depends upon the parties entering into a valid marriage. The agreement is unenforceable by a party who knew or had reason to believe that the marriage was void. ${ }^{106}$ Part 1 applies only to situations of a valid marriage or one which is void but thought to be valid. Arguably, it is superfluous to provide in section 37(4) that an agreement is unforceable by a spouse if that spouse knew and had reason to believe that the marriage was void. In effect, the innocent spouse in a putative marriage is entitled to make use of the provisions of Part 1, notwithstanding a prior agreement to contract out of Part 1, since the other spouse is precluded from enforcing the agreement to contract out. It must be noted, however, that it is possible to contract, within section 37, for purposes other than merely rendering the provisions of Part I inapplicable. One may question, therefore, whether such a contract, even if not enforceable under section (1) or (4), might nevertheless be valid for other purposes. For example, a release of rights to take on intestacy, if supported by consideration, may well be enforceable even if the agreement does not deal with all the items required by section 37 .

In order to ensure that agreements are not entered into in undue haste, or without a reasonable level of understanding, certain formal requirements are prescribed by section 38 . The spouse is required to acknowledge that he or she understands the terms of the agreement, understands the significance of the rights being given up, and that he or she is acting voluntarily, without compulsion on the part of the other spouse. Such an acknowledgement is to be executed by a lawyer, other than the lawyer acting for the other spouse, so that compete independence is maintained. Similar requirements for acknowledgements pertain in the case of dower releases, and the requirement of a lawyer's certificate can be found in the area of guarantees acknowledgements. While no certificate of independent advice is required by the act, such a document would prove extremely useful. It is to be hoped

145. Section 37(3)(a) provides that the agreement may specify other circumstances in which the division will operate.

146. Section 37(4) 
that such formal requirements will be treated, not as formalities to be dispensed with quickly, but as a necessary breathing space designed to ensure serious and proper consideration of the effects of an agreement rendering Part 1 inapplicable.

An unusual, and perhaps unintended result of the terms of section 37 is that it may be possible to contract out of the right to apply under the Family Relief Act. ${ }^{147}$ Hitherto this was not the case ${ }^{148}$ and the provisions of section 18 would appear to reinforce that view. However, Part 1, including section 18 , is not applicable where displaced by the appropriate agreement under section 37. It is doubtful that the act would be interpreted so as to allow parties to contract out of such a statute, and it is to be hoped that there will be an early amendment, taking section 18 out of Part 1 and placing it in Part 3, or a judicial decision to the effect that an agreement under section 37 cannot have that effect.

\section{CONCLUSION}

It has been said by Xenophon that it is not the function of the law to lead morality, but to follow it. The degree of acceptance of the new scheme of matrimonial property will determine whether the legislation has followed popular opinion and beliefs or has, in fact, attempted to change those opinions and beliefs.

In particular, a number of adjustments are necessary in order to accommodate the policy and purpose of the new legislation. It is no longer possible to adhere to fairly rigid property concepts and rules, making minor adjustments for the fact that competing parties are also husband and wife. It is now the case that the relationship of husband and wife controls property. Thus contribution of one party as a spouse and parent may create or extend proprietary interests. Thenecessity to adjudicate upon the nature of the relationship between the parties is quite a new obligation for the courts, and the approach adopted will be of considerable importance.

The statute contains a number of areas where the policy of the Act could be aborted if a liberal and constructive approach is not adopted. A restrictive interpretation of the factors mentioned in section 8, or the property subject to an order under Part 2 could well render the Act nugatory. So too would an overeagerness to depart from the norm of equal sharing. In each of these areas it is possible to sidestep the necessary determination of what constitutes a fair and equitable distribution of property between the parties. To do so, it is suggested, would constitute a serious dereliction of the court's overall duty to dispense justice.

For the practising bar, the statute represents a major re-examination of the methods of settling disputes between the parties. It is significant that the court can now do directly what it could previously do only indirectly. The difficulties of interpreting and applying a new statute involving new concepts should not be a reason to minimize the changes in practice brought about by the statute. Nor should the novelty of the legislation be a reason to avoid the exercise of the power of the court. To a large extent, the members of the profession control the ability of the court to pronounce upon the terms of the Act, and to put some flesh on the bones of the Act.

147. R.S.A. 1970, c. 134

148. Re Rist Estate, supra n. 139 